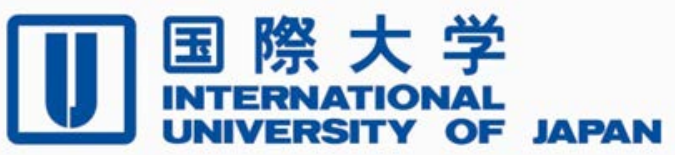

Economics \& Management Series

EMS-2020-01

\title{
Economic Tertiarization and Regional Income Inequality in a Decentralized Indonesia: A Bi- dimensional Inequality Decomposition Analysis
}

\author{
Armida Alisjahbana \\ Faculty of Economics and Business \\ Padjadjaran University
}

Takahiro Akita

IUJ Research Institute,

International University of Japan

January 2020

IUJ Research Institute

International University of Japan

These working papers are preliminary research documents published by the IUJ research institute. To facilitate prompt distribution, they have not been formally reviewed and edited. They are circulated in order to stimulate discussion and critical comment and may be revised. The views and interpretations expressed in these papers are those of the author(s). It is expected that the working papers will be published in some other form. 


\title{
Economic Tertiarization and Regional Income Inequality in a Decentralized Indonesia: A Bi-dimensional Inequality Decomposition Analysis
}

\author{
Armida Alisjahbana \\ Professor, Faculty of Economics and Business, Padjadjaran University (on leave) \\ e-mail: armida.alisjahbana@unpad.ac.id \\ Takahiro Akita* \\ Visiting Research Fellow, IUJ Research Institute, International University of Japan \\ e-mail: akita@iuj.ac.jp, Tel: +81-90-2728-0272, ORCID: 0000-0002-7325-1922
}

\begin{abstract}
This study attempts to explore the determinants of interprovincial income inequality in Indonesia from 2005 to 2013 by using a bidimensional inequality decomposition method. It tries, particularly, to analyze how economic tertiarization and concurrent output deindustrialization have affected interprovincial inequality. The bidimensional inequality decomposition method decomposes interprovincial inequality as measured by the squared populationweighted coefficient of variation in two dimensions, namely, by regional groups and industrial sectors. While deindustrialization has lowered the relative importance of manufacturing in determining overall interprovincial inequality, manufacturing activities are still very unevenly distributed among regions and provinces. The government needs to implement policies that are conducive to the balanced development of non-oil and gas manufacturing industries based on regional comparative advantages and disadvantages, where further development of economic infrastructures and human resources, particularly outside Java-Bali, is essential. Meanwhile, economic tertiarization has raised the importance of service activities in determining overall interprovincial inequality, particularly inequality within Java-Bali. The tertiary sector accounts for more than half of total GDP in Java-Bali, and many service activities, such as IC, banking, business services and private services, are concentrated in Jakarta and neighboring districts. Particularly, with the advancement of IC technologies, the IC sector has been expanding rapidly. Together with banking, business services and private services, further development of the IC sector is likely to increase interprovincial inequality in Java-Bali unless policies that could facilitate geographical dispersion of these service activities are implemented.
\end{abstract}

Key words: regional income inequality; Indonesia; economic tertiarization; deindustrialization; bi-dimensional inequality decomposition

\footnotetext{
* Akita is grateful to the Japan Society for the Promotion of Science (Grant-in-Aid for Scientific Research No. 17K03723 and 18K01589).
} 


\section{Economic Tertiarization and Regional Income Inequality in a Decentralized Indonesia: A Bi-dimensional Inequality Decomposition Analysis}

\section{Introduction}

Indonesia has undergone substantial structural changes over the last three decades (Table 1 and Figure 1). The GDP share of the agricultural sector was $21 \%$ in 1983 , but has declined gradually to $13 \%$ in 2013 , while the mining sector has experienced a prominent decrease from $19 \%$ to $7 \%$. On the other hand, the tertiary sector has raised its GDP share, particularly after the Asian financial crisis; in 2013, it accounted for about half of total GDP. Meanwhile, the manufacturing sector exhibited an inverted U-shaped pattern. In the 1980s and 1990s, under the Suharto's New Order Regime, its GDP share has increased gradually from $16 \%$ to $26 \%$; but, after reaching the peak in the late 1990s, it has become stable. Since the early 2000s, the GDP share has been declining, and in 2013, it went down to $23 \%$. Economic tertiarization seems to have been associated with deindustrialization since the Asian financial crisis. Indonesia's output deindustrialization appears to be pre-mature in the sense that it started at a much lower development level than most developed countries (Rodrik, 2016).

Changes in industrial structure are associated with the changes in the geographical distribution of economic activities, as shown in Table 2, where Indonesia is divided into five regions, i.e., Sumatra, Java-Bali, Kalimantan, Sulawesi and Eastern Indonesia. When mining is included, Sumatra and Kalimantan regions lowered their GDP shares from 1983 to 2013 due primarily to the declining share of oil and gas production in the provinces of Aceh, Riau and East Kalimantan (from 27\% to 21\% in Sumatra and from $9 \%$ to $8 \%$ in Kalimantan). On the other hand, Java-Bali region raised its GDP share from $58 \%$ to $63 \%$ in the same period, where the three adjacent provinces of Jakarta, West Java and Banten seem to have contributed most to the rise. ${ }^{1}$ Sulawesi region also increased its GDP share from 3\% to 5\%. As the most populous province in Sulawesi, accounting for almost half of the region's population and one of rapidly

\footnotetext{
1 Banten was separated from West Java in 2000 as a new province.
} 
growing provinces in Indonesia, South Sulawesi contributed most to the rise. ${ }^{2}$ Meanwhile, Eastern Indonesia did not exhibit a significant change in its GDP share.

Despite these structural changes, large disparities in socio-economic indicators persist among its regions and provinces due largely to unequal distributions of resource endowments, public infrastructure and economic activities. At the provincial level, the ratio of the largest to smallest per capita GDP has been very high at around 15-16 over the last decade, whether the mining sector is included or not (Table 3). The largest per capita GDP was registered by the capital province of Jakarta. When mining is included, Jakarta is followed by East Kalimantan, Riau Islands ${ }^{3}$, West Papua ${ }^{4}$ and Riau in 2013 (Table 3a). When mining is excluded, Riau Islands moved to the second position, which is followed by East Kalimantan, West Papua and East Java (Table 3b). On the other hand, whether mining is included or not, East Nusa Tenggara registered the smallest in 2013, followed by the provinces of Maluku and North Maluku. ${ }^{5}$ These provinces are, in fact, all in Eastern Indonesia. In order to reduce interregional inequalities in welfare levels and to cope with periodic secessionist movements, Indonesia embarked on political, administrative and fiscal decentralization in 2001; but, its effects on interregional inequalities remain uncertain.

Against this background, this study attempts to explore the determinants of interprovincial inequality in per capita GDP in a decentralized Indonesia from 2005 to 2013 by using a bi-dimensional inequality decomposition method. Particularly, it tries to analyze how economic tertiarization and concurrent deindustrialization have

\footnotetext{
${ }^{2}$ Here, the province of South Sulawesi excludes West Sulawesi, which was established in 2004 by being split off from South Sulawesi.

${ }^{3}$ The province of Riau Islands was established in 2002 by being split off from Riau and includes Batam and Bintan islands, which are located close to Singapore. Due to its large-scale non-oil and gas manufacturing activities, the manufacturing sector accounted for about half of its total GDP in 2013.

${ }^{4}$ Due to the development of a large-scale LNG (liquid natural gas) plant, West Papua (formerly West Irian Jaya) increased its GDP share substantially, though the share was still very small at $0.9 \%$ in 2013 (Table 2). The manufacturing sector, including LNG, accounted for almost half of West Papua's GDP. We should note that West Papua's population is less than 1 million, the second least populous province in Indonesia next to North Kalimantan, the youngest province established in 2012. Despite its very high per capita GDP, the province registered the highest incidence of poverty in Indonesia at around 20\%, indicating the presence of natural resource enclaves.

${ }^{5}$ The two Nusa Tenggara provinces (East and West) have been the poorest provinces in Indonesia, in which about $15 \%$ of their population lived below the national poverty line in 2013 . We should note, however, that unemployment rate is very low in East Nusa Tenggara at less than two-thirds of the national rate, indicating a high level of informality in employment. Meanwhile, North Maluku, which was separated from Maluku as a new province in 1999 and one of the least populous provinces in Indonesia, is a peculiar province; though the province registers the third lowest per capita GDP, its incidence of poverty is relatively low.
} 
affected interprovincial inequality. The bi-dimensional inequality decomposition method decomposes interprovincial inequality in per capita GDP, as measured by the population-weighted coefficient of variation (hereafter, WCV), in two dimensions, i.e., by regional groups and GDP components (industrial sectors). The WCV satisfies several desirable properties as a measure of inequality, such as anonymity, income homogeneity, population homogeneity and the Pigou-Dalton transfer principle (Anand, 1983). Furthermore, it is decomposable by factor components (Shorrocks, 1982). Since the squared $W C V$ belongs to the population-weighted generalized entropy class of inequality measures, it is also decomposable by population sub-groups (Shorrocks, 1980). Therefore, the bi-dimensional inequality decomposition method can examine the contributions of GDP components (industrial sectors) to within-region and between-region inequalities in a coherent framework. ${ }^{6}$

\section{Literature Review}

Numerous studies have been performed to analyze regional development dynamics and interregional inequalities in Indonesia. Among the recent studies that have examined the determinants of interregional inequalities using regional GDP data are Akita and Lukman (1995), Garcia and Soelistianingsih (1998), Tadjoeddin, Suharyo and Mishra (2001), Akita and Alisjahbana (2002), Akita (2003), Milanovic (2005), Resosudarmo and Vidyattama (2006), Hill (2008), Hill, Resosudarmo and Vidyattama (2008), Akita and Miyata (2010), Vidyattama (2010), Akita, Kurniawan and Miyata (2011), Vidyattama (2013), Hill and Vidyattama (2014), and Hill and Vidyattama (2016).

Based on provincial GDP data from 1975 to 1992, Akita and Lukman (1995) conducted an inequality decomposition analysis by GDP components (i.e., industrial sectors) using the $W C V$ to explore the determinants of inter-provincial inequality. Hill, Resosudarmo and Vidyattama (2008) and Hill and Vidyattama (2016) used updated data sets of provincial GDP, respectively, for the periods from 1970-2004 and 19752010, to analyze inter-provincial inequality in per capita GDP with the WCV. Meanwhile, Garcia and Soelistianingsih (1998) examined the absolute and conditional

6 The detailed account of the method is given in Section 3. 
$\beta$-convergence among provinces using provincial GDP for the period from 19751993. ${ }^{7}$ Hill, Resosudarmo and Vidyattama (2008) updated the provincial data set to analyze $\beta$-convergence for the period 1975-2002, while Vidyattama (2013) examined whether the spatial neighborhood effect is significant in $\beta$-convergence using provincial and district-level GDP data from 1999-2008.

Tadjoeddin, Suharyo and Mishra (2001) and Akita and Alisjahbana (2002) estimated regional income inequality for the period from 1993-98; but they used district-level GDP data. ${ }^{8}$ While Tadjoeddin, Suharyo and Mishra (2001) measured regional inequality using the Gini coefficient, Theil indices and the WCV, Akita and Alisjahbana (2002) conducted a two-stage inequality decomposition analysis using the Theil indices to investigate the determinants of regional inequality in per capita GDP across districts. As discussed above, Vidyattama (2013) also used district-level GDP data, but the study focused on an analysis of $\beta$-convergence across districts for 19992008.

Akita, Kurniawan and Miyata (2011) conducted a bi-dimensional inequality decomposition analysis using provincial GDP data from 1983 to 2004 to explore the determinants of interprovincial inequality in per capita GDP. Our study is similar to Akita, Kurniawan and Miyata (2011) in terms of the method. But it updates their study and analyzes interprovincial inequality from 2005 to 2013. Our study also differs from theirs in that it uses GDP data by 33 industrial sectors, while their study used GDP data by 9 industrial sectors. Since these 33 sectors include 3 manufacturing subsectors and 18 tertiary subsectors, our study could analyze, in more detail, how economic tertiarization and concurrent deindustrialization have affected the determinants of interprovincial inequality (see Table A1 in Appendix for the sector classification). ${ }^{9}$

\section{Methods and the Data}

\footnotetext{
7 Barro and Sala-i-Martin (1991) advanced the method for $\beta$-convergence analysis among countries and regions, which is described in detail in Section 3.

8 Districts here refer to regencies (kabupaten) and cities (kota). Since the two decentralization laws (Law 22/1999 on regional government and Law 25/1999 on fiscal decentralization) were implemented in 2001, a number of new districts have been created by being split off from existing districts. In 2001, there were around 350 districts; but since then the number of districts has increased substantially and now there were more than 500 districts.

9 Tertiary subsectors are sectors from 16 to 33 in Table A1.
} 


\subsection{Methods}

\section{Analysis of $\boldsymbol{\beta}$ Convergence Across Provinces}

Since provinces in Indonesia have similar preferences, savings rates, technologies and institutions, they have similar steady states. Thus, they are likely to converge in the absolute sense; that is, poor provinces tend to grow faster than rich provinces. To examine whether Indonesian provinces have converged in per capita GDP in the absolute sense over the study period, we conduct an analysis of $\beta$ convergence by using the following non-linear regression equation (Barro and Sala-iMartin, 1991).

$$
\left(\frac{1}{T}\right) \ln \left(\frac{y_{i T}}{y_{i 0}}\right)=a-\frac{1-e^{-\beta T}}{T} \ln \left(y_{i 0}\right)+u_{i}
$$

where $y_{i 0}, y_{i T}, \beta$ and $u_{i}$ are, respectively, per capita GDP of province $i$ in the initial year, per capita GDP of province $i$ in the terminal year, speed of convergence and error term. $\left(\frac{1}{T}\right) \ln \left(\frac{y_{i T}}{y_{i 0}}\right)$ in equation (1) is the average annual growth rate of per capita GDP between 0 and T. If there is absolute convergence among the provinces, $b=-\frac{1-e^{-\beta T}}{T}$ should have a negative sign.

\section{Bi-dimensional Decomposition of Interprovincial Inequality by the Squared Population-weighted Coefficient of Variation}

To analyze the effects of the changes in industrial and spatial structures on interprovincial inequality, we conduct a bi-dimensional decomposition analysis using the squared population-weighted coefficient of variation (squared WCV). Suppose that a country consists of $m$ regions and region $i$ is composed of $n_{i}$ provinces. Then, interprovincial inequality in per capita GDP can be measured by the following squared $W C V$.

$$
C V^{2}=\frac{1}{y^{2}} \sum_{i=1}^{m} \sum_{j=1}^{n_{i}} \frac{p_{i j}}{p}\left(y_{i j}-y\right)^{2}
$$

where $y_{i j}, p_{i j}, y$ and $p$ are, respectively, per capita GDP of province $j$ in region $i$, population of province $j$ in region $i$, per capita GDP of a country and total population of a country. Interprovincial inequality in per capita GDP can also be measured by the population-weighted generalized entropy class of measures (hereafter referred to as WGE) as follows. 


$$
\begin{aligned}
W G E_{\alpha} & =\frac{1}{\alpha(\alpha-1)} \sum_{i=1}^{m} \sum_{j=1}^{n_{i}} \frac{p_{i j}}{p}\left[\left(\frac{y_{i j}}{y}\right)^{\alpha}-1\right] \quad \text { when } \alpha \neq 0,1 \\
W G E_{0} & =\sum_{i=1}^{m} \sum_{j=1}^{n_{i}}\left(\frac{p_{i j}}{p}\right) \ln \left(\frac{y}{y_{i j}}\right) \\
W G E_{1} & =\sum_{i=1}^{m} \sum_{j=1}^{n_{i}}\left(\frac{p_{i j}}{p}\right)\left(\frac{y_{i j}}{y}\right) \ln \left(\frac{y_{i j}}{y}\right)
\end{aligned}
$$

$W G E_{0}$ and $W G E_{1}$ are usually called the Theil indices $L$ and $T$, respectively.

When $\alpha=2$, we have

$$
W G E_{2}=\frac{1}{2} \sum_{i=1}^{m} \sum_{j=1}^{n_{i}} \frac{p_{i j}}{p}\left[\left(\frac{y_{i j}}{y}\right)^{2}-1\right]=\frac{1}{2 y^{2}} \sum_{i=1}^{m} \sum_{j=1}^{n_{i}} \frac{p_{i j}}{p}\left(y_{i j}-y\right)^{2}
$$

From equations (2) and (4), we have $W G E_{2}=\frac{1}{2} C V^{2}$. In other words, squared $W C V$ belongs to WGE. WGE can be decomposed additively into the within- and betweenregion inequality components; thus, squared $W C V$ can be written as follows (Shorrocks, 1980; Anand, 1983). ${ }^{10}$

$$
C V^{2}=C V_{W}+C V_{B} \text {. }
$$

$C V_{W}=\sum_{i=1}^{m}\left(\frac{p_{i}}{p}\right)\left(\frac{y_{i}}{y}\right)^{2} C V_{i}^{2}$ is the within-region inequality component, while $C V_{B}=\frac{1}{y^{2}} \sum_{i=1}^{m} \frac{p_{i}}{p}\left(y_{i}-y\right)^{2}$ is the between-region inequality component, where $p_{i}, y_{i}$ and $C V_{i}^{2}$ are, respectively, total population of region $i$, per capita GDP of region $i$ and squared $W C V$ among provinces in region $i$. It should be noted that $C V_{W}$ is not a weighted average of $C V_{i}^{2}$, since the weights do not sum to unity.

We suppose next that total provincial GDP is composed of $K$ GDP components (industrial sectors). Since squared $W C V$ can also be decomposed additively by GDP components, region i's within-region inequality can be expressed as follows (Shorrocks, 1982).

$$
C V_{i}^{2}=\sum_{k=1}^{K} w_{i k} C O V_{i k}
$$

$\operatorname{COV}_{i k}=\frac{1}{y_{i} y_{i k}} \sum_{j=1}^{h_{i}} \frac{p_{i j}}{p_{i}}\left(y_{i j}-y_{i}\right)\left(y_{i j k}-y_{i k}\right)$ is the population-weighted coefficient of covariation (hereafter referred to as WCOV) between total per capita GDP and per capita GDP from component $k$ in region $i$, where $w_{i k}, y_{i k}$ and $y_{i j k}$ are, respectively, GDP share of component $k$ in region $i$, per capita GDP from component $k$ in region $i$ and per capita GDP from component $k$ in province $j$ and region $i$.

10 Similarly, $W G E_{0}$ (Theil index $L$ ) and $W G E_{1}$ (Theil index $T$ ) can be decomposed additively into the within- and between-region inequality components: $L=L_{\mathrm{W}}+L_{\mathrm{B}}$ and $T=T_{\mathrm{W}}+T_{\mathrm{B}}$. 
Similarly, the between-region inequality can be decomposed additively by GDP components as follows.

$$
C V_{B}=\sum_{k=1}^{K} w_{k} \operatorname{COV}_{k}
$$

$\operatorname{COV}_{k}=\frac{1}{(y)\left(y_{\cdot k}\right)} \sum_{i=1}^{m} \frac{p_{i}}{p}\left(y_{i}-y\right)\left(y_{i k}-y_{\cdot k}\right)$ is WCOV between total per capita GDP and per capita GDP from component $k$, where $w_{k}$ and $y_{\cdot_{k}}$ are, respectively, GDP share of component $k$ and per capita GDP from component $k$ in a country.

Substituting equations (6) and (7) into equation (5), we obtain the following bidimensional decomposition equation:

$$
C V^{2}=\sum_{i=1}^{m}\left(\frac{p_{i}}{p}\right)\left(\frac{y_{i}}{y}\right)^{2} \sum_{k=1}^{K} w_{i k} \operatorname{COV}_{i k}+\sum_{k=1}^{K} w_{k} \operatorname{COV}_{k}
$$

If we divide this equation by $C V^{2}$, we have

$$
1=\sum_{i=1}^{m}\left(\frac{p_{i}}{p}\right)\left(\frac{y_{i}}{y}\right)^{2} \sum_{k=1}^{K} w_{i k} s_{i k}+\sum_{k=1}^{K} w_{k} s_{k}=\sum_{i=1}^{m} \sum_{k=1}^{K} c_{i k}+\sum_{k=1}^{K} c_{k}
$$

where $s_{i k}=\frac{C O V_{i k}}{C V^{2}}$ and $s_{k}=\frac{C O V_{k}}{C V^{2}} . \quad c_{i k}=\left(\frac{p_{i}}{p}\right)\left(\frac{y_{i}}{y}\right)^{2} w_{i k} s_{i k}$ is the contribution of region i's within-region inequality for component $k$ to overall interprovincial inequality, while $c_{k}=w_{k} s_{k}$ is the contribution of between-region inequality for component $k$ to overall interprovincial inequality. If there are 3 regions and 9 industrial sectors, then including components for the between-region inequality, there are $(3+1)$ $\times 9=36$ components in equation (8).

By dividing equation (6) by $C V_{i}^{2}$, we have

$$
1=\sum_{k=1}^{K} w_{i k} r_{i k} \text {. }
$$

where $r_{i k}=\frac{C O V_{i k}}{C V_{i}^{2}}$ is called the relative concentration coefficient of GDP component $k$ in the within-region inequality of region $i$. If $r_{i k}$ is greater (smaller) than one, then GDP component $k$ is an inequality-increasing (decreasing) component in region $i$. In other words, if GDP component $k$ was eliminated, the within-region inequality of region $i$ would have been smaller (larger). Similarly, by dividing equation (7) by $C V_{B}$, we have

$$
1=\sum_{k=1}^{K} w_{k} r_{k}
$$

where $r_{k}=\frac{C O V_{k}}{C V_{B}}$ is the relative concentration coefficient of GDP component $k$ in the between-region inequality.

It should be noted that squared $W C V$ can be decomposed also into the $W C V$ and 
WCOV terms as follows.

$$
C V^{2}=\sum_{k=1}^{K}\left(w_{k}^{2} C V_{k}^{2}+\sum_{h \neq k} w_{k} w_{h} C O V_{k h}\right)
$$

where $C V_{k}^{2}$ and $C O V_{k h}$ are, respectively, $W C V$ for GDP component $K$ and $W C O V$ between GDP components $k$ and $h$. When an economy consists of 3 industrial sectors, equation (11) can be written as follows (Akita and Lukman, 1995).

$$
\begin{gathered}
C V^{2}=w_{1}^{2} C V_{1}^{2}+w_{2}^{2} C V_{2}^{2}+w_{3}^{2} C_{3}^{2}+2 w_{1} w_{2} \operatorname{COV}_{12}+2 w_{1} w_{3} \operatorname{COV}_{13} \\
+2 w_{2} w_{3} \operatorname{COV}_{23}
\end{gathered}
$$

\subsection{The Data}

Interprovincial inequality is measured by using provincial GDP at constant 2000 prices for the period from 2005-2013. The data set is constructed based on various issues of Gross Regional Domestic Product of Provinces in Indonesia by Industrial Origin published by the Central Bureau of Statistics (CBS, various issues). It contains provincial GDP by 33 industrial sectors for 33 provinces (see Table A1 in Appendix for the sector classification). To conduct a bi-dimensional decomposition analysis, 33 industrial sectors are classified into the 9 sectors: (1) agriculture; (2) mining; (3) manufacturing; (4) electricity, gas and water; (5) construction; (6) trade, hotel and restaurant; (7) transportation and communication; (8) financial and business services and (9) other services. On the other hand, 33 provinces are grouped into the 3 regions: Region 1 includes Sumatra and Kalimantan; Region 2 includes Java and Bali; and Region 3 consists of Sulawesi and Eastern Indonesia (see Table 2).

Natural resources are unevenly distributed, and even under the law on fiscal decentralization implemented in 2001 and revised in 2004, not all the benefits from resource-based activities have accrued to provincial economies. ${ }^{11}$ As in most previous studies, therefore, interprovincial inequality is calculated including and excluding mining. Since Jakarta, as the center of economic activities, accounts for $18 \%$ of total

\footnotetext{
11 Under fiscal decentralization, revenues generated by natural resources must be shared between the central government and regional governments. Provinces and districts are entitled to receive $15.5 \%$ of oil revenue, $30.5 \%$ of gas revenue, and $80 \%$ of revenues from other natural resources (i.e., forestry, fishery, general mining and geothermal energy); with a few exceptions, of the amount allocated to the producing regions, $20 \%$ goes to the province, $40 \%$ to the producing districts, and the remaining $40 \%$ is shared equally among the non-producing districts in the province (Bahl and Tumennasan, 2004; Brodjonegoro and Martinez-Vazquez, 2005; Soesastro and Atje, 2005). It should be noted, however, that the special autonomous provinces of Aceh, West Papua and Papua receive $70 \%$ of their oil and gas revenues (Brodjonegoro and Martinez-Vazquez, 2005; Agustina, Schulze and Fengler, 2012).
} 
GDP and its per capita GDP is more than 4.5 times the national average, the inclusion of Jakarta as a separate province will affect interprovincial inequality substantially; thus, interprovincial inequality is measured also by merging Jakarta with West Java presumptively.

\section{Empirical Results}

\subsection{Levels and Trends of Interprovincial Inequalities}

Figure 2 presents interprovincial inequality in per capita GDP at constant 2000 prices for the period from 1983 to 2013 as measured by the squared WCV, where interprovincial inequality for 1983-2004 is obtained from Akita, Kurniawan and Miyata (2011). ${ }^{12}$ When mining is included, there was a clear declining trend over the period. But the declining speed has been getting smaller. The squared WCV was 1.16 in 1983 , but it declined prominently to 0.86 in 1989 . Interprovincial inequality became stable for the period from 1989 to 1997 , at around $0.83-0.85$ by the squared WCV. Indonesia faced the severe financial crisis between 1997 and 1999, during which interprovincial inequality fell sharply to 0.76 . After the financial crisis, however, interprovincial inequality became stable again; the squared $W C V$ was around 0.75 between 1999 and 2004.

For the study period from 2005 to 2013 , interprovincial inequality exhibited a slight declining trend; the squared $W C V$ decreased from 0.74 to 0.67 . To examine whether there was a $\beta$ convergence across 33 provinces for the period, a $\beta$ convergence analysis is performed using equation (1). Since there are differences between the Java-Bali region and the other regions in terms of preference, technology, savings rate and institution, a dummy variable is introduced in the regression equation ( 1 for Java-Bali provinces; 0 for the other provinces). The result is presented in Table 4. The coefficient of the log initial per capita GDP is statistically significant at the 5\% level and has a negative sign, implying a conditional $\beta$ convergence across provinces rather than an absolute $\beta$ convergence over the study period. That is, provinces with smaller initial per capita GDP tended to grow faster than districts with larger per capita

\footnotetext{
12 It should be noted that interprovincial inequality for 1983-2004 is measured across 26 provinces, while for 2005-2013, across 33 provinces.
} 
GDP after controlling for differences between the Java-Bali region and the other regions. However, if the period is divided into two subperiods, 2005-2009 and 20092013, conditional $\beta$ convergence occurred in the first subperiod (2005-2009) and there was no significant $\beta$ convergence in the second subperiod (2009-2013). In the first sub-period, the speed of convergence was $1.4 \%$ a year, implying that it takes almost 50 years for the difference between the current and steady state levels of per capita GDP to reduce by half.

Despite a declining trend, interprovincial inequality is still very high. In 2013, the ratio of the largest to smallest per capita GDP (Jakarta/East Nusa Tenggara) was very high at 15.9, and Jakarta's per capita GDP was 4.6 times the national average and 1.6 times the second largest (East Kalimantan) (see Table 3a). These observations suggest that Jakarta is an outlier. If Jakarta is presumptively merged with the adjacent province of West Java and interprovincial inequality is measured among 32 provinces, the squared $W C V$ is reduced substantially. According to Figure 2, the squared $W C V$ was 0.79 in 1983 , but has declined gradually to 0.20 in 2013 . These inequality values are much smaller than the values among 33 provinces. Over the study period from 2005 to 2013, a statistically significant $\beta$ convergence is observed also across 32 provinces. The speed of convergence at $1.7 \%$ is, however, faster than that among 33 provinces. Among the 32 provinces, East Kalimantan had the highest per capita GDP, which was 10.2 times the smallest in 2013 (Table 3a). The per capita GDP of West Java, which now includes Jakarta, was only 1.5 times the national average.

As in the previous studies, interprovincial inequality among 33 provinces is measured by excluding mining. The squared $W C V$ has been smaller than that including mining, but this was until 2006. The difference in the squared $W C V$ has been getting smaller; in 1983, it was 0.37 , but declined to 0.01 in 2006. Since 2007, the squared $W C V$ with mining excluded has been larger than that with mining included. Natural resources are distributed very unevenly, thus interprovincial inequality in per capita GDP from mining is very high. However, as the GDP share of mining has decreased gradually (see Table 1), its contribution to total interprovincial inequality has been getting smaller. This has apparently reduced the difference.

Like in the case where mining is included, if Jakarta is merged with West Java hypothetically, the level of interprovincial inequality is decreased substantially. Over 
the period from 1983 to 2013, the squared $W C V$ has been very stable, ranging between 0.17 and 0.24 , though there was a slight declining trend from 2005. In 2013, Riau Islands, which includes Batam and Bintan islands, now had the largest per capita GDP (see footnote 3, for the economy of Riau Islands), which is followed next by East Kalimantan and West Java (see Table 3b). The largest to smallest per capita GDP (Riau Islands/East Nusa Tenggara) was 8.3 in 2013.

\subsection{Interprovincial Inequalities by Industrial Sectors}

As discussed above, whether mining is included or not, interprovincial inequality has been declining gradually over the period from 2005-2013. But, it is still high, even if Jakarta is merged with West Java hypothetically. To explore the determinants of interprovincial inequality, we calculate interprovincial inequality by industrial sector for each region by the $W C V$. The result is presented in Table 5, while the change in industrial structure by region is shown in Table 6 . Whether mining is included or not, Region 2 (Java-Bali) had the largest interprovincial inequality at 0.9 by the $W C V$. When mining is included, Region 1 (Sumatra and Kalimantan) had the second largest inequality, since it includes two major resource-rich provinces, Riau and East Kalimantan. ${ }^{13}$ As the GDP share of mining has declined, however, Region 1's interprovincial inequality has been getting smaller. When mining is excluded, Region 3 (Sulawesi and Eastern Indonesia) had the second largest interprovincial inequality in 2013. It should be noted that Region 1 reduced its interprovincial inequality over the period even if mining is excluded.

In Indonesia as a whole, mining had the largest interprovincial inequality among 9 industrial sectors in 2013, and this was followed by financial and business services and construction. On the other hand, the smallest was registered by agriculture, followed by the electricity, gas and water sector and manufacturing. Each region, however, shows a distinct pattern of interprovincial inequalities. In Region 1, the mining sector had the largest interprovincial inequality, reflecting very uneven spatial distribution of natural resources within the region, and it was followed by manufacturing and construction. Despite a declining trend, the manufacturing sector had a high interprovincial inequality in the region, indicating that manufacturing

13 In Riau and East Kalimantan, mining contributed more than $40 \%$ of their GDP and these two provinces accounted for 70\% of Region 1's GDP from mining in 2013. 
activities, mainly resource-based activities, have been developed very unevenly across provinces. The agricultural sector, on the other hand, had a very small interprovincial inequality and exhibited a slight declining trend.

In Region 2, financial and business services had the largest interprovincial inequality, which was followed by construction and the transportation and communication sector. Particularly, the financial and business services sector had a very large interprovincial inequality, though it exhibited a declining trend. When Jakarta is merged with West Java, however, the sector's inequality drops substantially. This implies that there is a very large disparity between Jakarta and the other Java-Bali provinces in financial and business activities. Though inequalities are smaller, construction and the transportation and communication sector also reduce their inequalities when Jakarta is merged with West Java. These observations imply that Region 2's very high interprovincial inequality is due mainly to a very high disparity in construction and tertiary activities between Jakarta and the other Java-Bali provinces. We should note here that in Jakarta, the tertiary sector accounted for three quarters of its total GDP in 2013, which is compared to $47 \%$ in the other Java-Bali provinces. This means that about $40 \%$ of Region 2's GDP from the tertiary sector is generated by Jakarta. ${ }^{14}$ When Jakarta is merged with West Java, Region 2's interprovincial inequality drops conspicuously from 0.9 to a little above 0.3 by the $W C V$, and in 2013, Region 2 had the smallest interprovincial inequality among three regions whether mining is included or not.

In Region 3, the mining sector had the largest interprovincial inequality in 2005, which is followed by manufacturing and construction. But, it lowered its inequality substantially over the study period. On the other hand, due mainly to the rapid development of liquid natural gas (LNG) in West Papua, the manufacturing sector raised its interprovincial inequality and surpassed mining (see footnote 4 , for the economy of West Papua). In 2013, it had the largest interprovincial inequality.

\subsection{Bi-dimensional Decomposition Analysis}

To explore the determinants of interprovincial inequality in a unified region-

\footnotetext{
14 Jakarta accounted for 70\% of Region 2's GDP from the financial and business services sector. It also constituted $60 \%$ of Region 2's GDP from the information and communication sector.
} 
industry framework, this study conducts a bi-dimensional inequality decomposition analysis using the squared WCV (see equations (5) and (8)). Table 7a presents the result for the case where mining is included. Much of interprovincial inequality is accounted for by the within-region inequality component, contributing more than $95 \%$ of overall inequality. ${ }^{15}$ Region 2 dominated the within-region component and raised its contribution to overall interprovincial inequality from $68 \%$ to $80 \%$ over the study period. Much of this increase was, however, attributable to the rise in the contribution of the tertiary sector, particularly the trade, hotel and restaurant sector and the transportation and communication sector. Meanwhile, Region 1 reduced its contribution from $27 \%$ to $15 \%$, and much of this decrease was due to the declining contributions of mining and manufacturing. With its small GDP share and low interprovincial inequality, Region 3 had a very small contribution.

When Jakarta is merged with West Java hypothetically, the contribution of the between-region inequality component is increased; but the within-region component still accounted for more than $85 \%$ of overall inequality. Region 1 is now the main contributor to overall interprovincial inequality, though its contribution has been decreasing gradually due to the declining contributions of mining and manufacturing. In 2013, Region 1's within-region inequality accounted for $48 \%$ of overall inequality. On the other hand, with Jakarta amalgamated with West Java, the contribution of Region 2 is reduced substantially, though over the study period it has risen from $25 \%$ to $34 \%$. This is again due to the rising contribution of the tertiary sector, particularly the trade, hotel and restaurant sector and the transportation and communication sector. Meanwhile, Region 3's contribution was 5\% in 2013, and the main contributor was manufacturing.

Table $7 \mathrm{~b}$ presents the result for the case where mining is excluded. The withinregion inequality component accounted for $95 \%$ of overall interprovincial inequality, where the contribution of Region 2 to overall inequality is increased to $87 \%$, while that of Region 1 is reduced to 6\% in 2013. Region 2's tertiary sector dominated the withinregion component and raised its contribution to overall interprovincial inequality from $65 \%$ to $71 \%$ over the study period. When Jakarta is merged with West Java, the

\footnotetext{
15 If interprovincial inequality is measured by $W G E(1)$ (i.e., Theil index T), the contribution of the between-region inequality component gets larger, but the within-region inequality component still constitutes more than $90 \%$ of overall inequality.
} 
between-region inequality component raised its contribution conspicuously. It now accounted for $23 \%$ of overall interprovincial inequality in 2013, of which 10 percentage points were due to manufacturing's between-region inequality. As in the case where mining is included, when Jakarta is merged with West Java, the contribution of Region 2's within-region inequality is reduced prominently. However, Region 2 raised its contribution due to the rising contribution of the tertiary sector, and in 2013, its within-region inequality accounted for $47 \%$ of overall inequality. Meanwhile, Region 1 lowered its contribution from $39 \%$ to $25 \%$ due primarily to the declining contribution of manufacturing.

We can now identify several important determinants of interprovincial inequality in Indonesia. First, mining's interprovincial inequality is still the main determinant of Region 1's within-region inequality, though its contribution has been declining gradually. When mining is excluded, however, the manufacturing sector dominated Region 1's inequality, as it accounted for more than half of the inequality. As measured by the $W C V$, its inequality was 1.2 in 2013, which was still very high (see Table 5). To see which manufacturing subsectors contribute most to manufacturing's interprovincial inequality in Region 1, we conducted an inequality decomposition analysis by manufacturing subsectors using equation (9). The result is presented in Table 8. Among three manufacturing subsectors, non-oil and gas manufacturing has played an increasingly important role in determining manufacturing's interprovincial inequality as its contribution has risen from $39 \%$ to $76 \%$. Non-oil and gas manufacturing activities are very unevenly distributed in Region 1 with the WCV being 1.3, which is very high. They are concentrated in two provinces, i.e., North Sumatra and Riau Islands; their combined share was $48 \%$ in Region 1's GDP from non-oil and gas manufacturing in 2013. ${ }^{16}$ If we add South Sumatra and Riau (third and fourth largest contributors), the share increases to $67 \%$. Meanwhile, no significant non-oil and gas manufacturing activities exists in the provinces of Bengkulu, Central Kalimantan and Aceh with their shares being merely $0.4 \%, 1.4 \%$ and $1.6 \%$, respectively, in $2013 .^{17}$

\footnotetext{
${ }^{16}$ North Sumatra includes the Medan metropolitan area, which consists of Medan city, Binjai city, Deli Serdang regency and Karo regency. This area is the biggest metropolitan area outside Java and serves as a hub for western Indonesia.

${ }^{17}$ In these three provinces, non-oil and gas manufacturing accounted for merely 4-6\% of their total GDP in 2013, which was much smaller than Region 1's figure of $14 \%$.
} 
Second, the tertiary sector has played an important role in determining Region 2's within-region inequality. Among four tertiary sectors, the financial and business services sector and the trade, hotel and restaurant sector contributed a lot to Region 2's inequality. Even if Jakarta is merged with West Java hypothetically, these two sectors have played an important role and their combined contribution to Region 2's inequality was $50 \%$ in 2013 . Though the contribution is not large as compared to these two sectors, the transportation and communication sector raised its contribution to Region 2's inequality notably. To explore which subsectors among 18 tertiary subsectors contribute most to Region 2's within-region inequality, we conducted an inequality decomposition analysis by tertiary subsectors using equation (9). The result is presented in Table 9. Five subsectors can be identified as major contributors, namely, wholesale and retail trade, information and communication, banking, business services, and private services. Among these five subsectors, wholesale and retail trade is an inequality-decreasing component as its relative concentration coefficient is smaller than one (see equation (9)). On the other hand, information and communication, banking, business service, and private services serve as inequality-increasing components in the tertiary sector as their relative concentration coefficients exceed one. This implies that if these four subsectors raise their GDP shares, Region 2's withinregion inequality will be even higher. Particularly, the information and communication sector should be paid attention to, as its GDP share has been rising rapidly and its contribution to tertiary sector's inequality has increased from $6 \%$ to $14 \%$ in the period. We should note that the information and communication sector is concentrated in Jakarta, accounting for about $60 \%$ of Region 2's GDP from this subsector. Banking and business services are also concentrated in Jakarta as the province constitutes around $80 \%$ of Region 2's GDP from the subsectors; but their GDP shares in the tertiary sector have been declining.

Third, the contribution of manufacturing to Region 2's within-region inequality has been declining as manufacturing's GDP share and interprovincial inequality have both decreased (Table 5 and 6). However, when Jakarta is merged with West Java, the manufacturing sector contributed 20\% of Region 2's within-region inequality in 2013. West Java accounted for 35\% of Region 2's GDP from manufacturing, while Jakarta $14 \%$. This is in contrast with the tertiary sector, where West Java and Jakarta 
constituted, respectively, $17 \%$ and $40 \%$ of Region 2's GDP from the tertiary sector. The manufacturing sector contributed $41 \%$ of West Java's total GDP, much larger than the national figure of $23 \%$. Though smaller than West Java, Banten generated $11 \%$ of Region 2's GDP from manufacturing; the manufacturing sector contributed almost half of its total GDP. Manufacturing activities appear to have been shifting from Jakarta to West Java and Banten, particularly to Jakarta's neighboring districts, such as Bogor, Depok, Tangerang and Bekasi, where West Java includes Bogor, Depok and Bekasi, while Banten includes Tangerang. It should be noted that besides the Jakarta metropolitan area, Region 2 contains the three largest metropolitan areas in Indonesia, namely, the Surabaya, Bandung and Semarang metropolitan areas. With their population exceeding 6 million, they serve to accommodate a variety of manufacturing activities.

Fourth, the construction sector had a relatively high interprovincial inequality and its contribution to overall inequality has risen from $7.8 \%$ to $9.7 \%$ as its GDP share has increased (see Table 7a). Particularly, its contribution to Region 2' within-region inequality was around $10 \%$ in 2013 , even if Jakarta is merged with West Java. Jakarta generated almost half of Region 2's GDP from construction, and if it is merged with West Java, the share goes up to $65 \%$. Fifth, though the contribution of Region 3 is very small as compared to Regions 1 and 2, it has been rising; but, the increase is due primarily to the development of a large scale LNG plant in West Papua (see Footnote 4). In Region 3, South Sulawesi dominates non-oil and gas manufacturing as it accounted for half of Region 3's GDP from non-oil and gas manufacturing in 2013. Sixth, the contribution of the between-region inequality was not large, but it has been rising when Jakarta is merged with West Java. The major contributor to the betweenregion inequality appears to have been the manufacturing sector, as it accounted for more than $40 \%$ of the between-region inequality. Region 2 dominates the manufacturing sector as it constituted three quarters of GDP from manufacturing in 2013; its manufacturing activities are mostly non-oil and gas activities. According to Table 6, manufacturing contributed 27\% of Region 2's total GDP in 2013, which is compared to $18 \%$ and $11 \%$ in Regions 1 and 3 respectively. 


\section{Conclusion}

This study explored the determinants of interprovincial inequality in Indonesia from 2005-2013 using the bi-dimensional inequality decomposition method. The following provides a summary of the findings. First, despite a declining trend, interprovincial inequality was still very high at around 0.7 by the squared populationweighted coefficient of variation; the largest per capita GDP registered by Jakarta was more than 15 times the smallest. Though there was a statistically significant conditional $\beta$ convergence across provinces in the period from 2005-2009, it takes almost 50 years for the difference between the current and steady state levels of per capita GDP to reduce by half.

Second, according to the bi-dimensional inequality decomposition analysis, whether mining is included or not, much of interprovincial inequality is accounted for by the within-region inequality component. While Region 2 (Java-Bali) dominated the within-region component and has raised its contribution to overall inequality due to the rising contribution of the tertiary sector, Region 1 (Sumatra and Kalimantan) has lowered its contribution due to the declining contributions of mining and manufacturing. With its small GDP share and low interprovincial inequality, the contribution of Region 3 (Sulawesi and Eastern Indonesia) was very small.

Third, although mining has reduced its contribution, it is still the main contributor to the within-region inequality of Region 1. If mining is excluded, however, the manufacturing sector dominated Region 1's inequality, where non-oil and gas manufacturing has played an increasingly important role. Fourth, the tertiary sector has played a pivotal role in the within-region inequality of Region 2. Among tertiary subsectors, wholesale and retail trade, information and communication (IC), banking, business services, and private services contributed a lot to Region 2's inequality. Of these five subsectors, IC, banking, business services and private services are mostly concentrated in Jakarta and have served to increase Region 2's within-region inequality. Particularly, the IC sector has raised its GDP share rapidly and its contribution to Region 2's inequality has increased substantially.

Fifth, the manufacturing sector has reduced its contribution to Region 2's withinregion inequality as its GDP share and interprovincial inequality have both declined. 
Manufacturing activities appear to have been shifting from Jakarta to West Java and Banten, particularly to Jakarta's neighboring districts, such as Bogor, Depok, Tangerang and Bekasi. In West Java and Banten, the manufacturing sector contributed more than $40 \%$ of their total GDP, which is much larger than the national figure of $23 \%$.

Sixth, the construction sector had a relatively high interprovincial inequality and its contribution to overall inequality has been rising as its GDP share has increased. In Region 2, construction activities are concentrated in Jakarta, generating almost half of its GDP from construction and have played an increasingly important role in Region 2 's within-region inequality. Finally, the between-region inequality was not large. But, if Jakarta is amalgamated with West Java hypothetically, its contribution to overall inequality has risen. The major contributor to the between-region inequality appears to have been the manufacturing sector. Region 2 dominated the sector as it accommodated three quarters of GDP from manufacturing.

While deindustrialization has lowered the relative importance of manufacturing in determining overall interprovincial inequality, manufacturing activities are still very unevenly distributed among regions and provinces. Non-oil and gas manufacturing activities are mostly located in Java-Bali, but they are expected to play an increasingly important role in interprovincial inequalities outside Java-Bali. With the development of economic infrastructures throughout Java-Bali, interprovincial inequality in manufacturing is likely to decrease in the region. But many provinces outside JavaBali lack economic infrastructures and human resources. Further development of nonoil and gas manufacturing industries would thus increase interprovincial inequalities outside Java-Bali, since these industries tend to be located where economic infrastructures and human resources are relatively abundant. The government needs to implement policies that are conducive to the balanced development of non-oil and gas manufacturing industries based on regional comparative advantages and disadvantages, where further development of economic infrastructures and human resources, particularly outside Java-Bali, is essential.

In contrast, economic tertiarization has raised the importance of service activities in determining overall interprovincial inequality, particularly inequality within JavaBali. The tertiary sector accounts for more than half of total GDP in Java-Bali, and 
many service activities, such as IC, banking, business services and private services, are concentrated in Jakarta and neighboring districts. Particularly, with the advancement of IC technologies, the IC sector has been expanding rapidly. Together with banking, business services and private services, further development of the IC sector is likely to increase interprovincial inequality in Java-Bali unless policies that could facilitate geographical dispersion of these service activities are implemented.

This study is not without limitations. The followings are some of the limitations of this study. First, this study focused on interprovincial income inequality during the Yudhoyono presidency due primarily to the unavailability of provincial data at 2000 constant prices after 2014. Second, since sectoral regional GDP data are not available at the district level (kabupaten/kota), this study is not able to analyze inter-district income inequality by sector. Third, since provincial GDP data for non-oil and gas manufacturing subsectors, such as food processing, textile, wood processing, metal and machinery industries, are not available, this study is not able to analyze interprovincial inequalities for these manufacturing subsectors.

\section{References}

Agustina, C.D.R.D., Schulze, G.G., Fengler, W. (2012). The regional effects of Indonesia's oil and gas policy: options for reform. Bulletin of Indonesian Economic Studies, 48(3), 369-397.

Akita, T. (2003). Decomposing regional income inequality in China and Indonesia using two-stage nested Theil decomposition method, Annals of Regional Science, $37(1), 55-77$.

Akita, T., and Alisjahbana, A. (2002). Regional income inequality in Indonesia and the initial impact of the economic crisis. Bulletin of Indonesian Economic Studies, 38, 201-22.

Akita, T. and Lukman, R.A. (1995). Interregional inequalities in Indonesia: A sectoral decomposition analysis for 1975-92. Bulletin of Indonesian Economic Studies, 31(2): 61-81.

Akita, T., and Miyata, S. (2010). The Bi-dimensional decomposition of regional inequality based on the weighted coefficient of variation. Letters in Spatial and Resource Sciences, 3(3), 91-100.

Akita, T., Kurniawan, P. A., and Miyata, S. (2011) Structural changes and regional income inequality in Indonesia: A bi-dimensional decomposition analysis. Asian Economic Journal, 25(1), 55-77. 
Anand, S. (1983). Inequality and Poverty in Malaysia: Measurement and Decomposition. New York: Oxford University Press.

Bahl, R., Tumennasan, B. (2004). How should revenues from natural resources be shared in Indonesia?, in Alm, J., Martinez-Vazquez, J. and Indrawati, S. M. Eds. Reforming Intergovernmental Fiscal Relations and the Rebuilding of Indonesia, pp. 199-233. Edward Elgar, Cheltenham.

Barro, R. J., and Sala-i-Martin, X. (1991). Convergence across states and regions, Brookings Papers on Economic Activity, 1, 107-182.

Brodjonegoro, B., Martinez-Vazquez, J. (2005). An analysis of Indonesia's transfer system: recent performance and future prospects, in Alm, J., Martinez-Vazquez, J. and Indrawati, S. M. Eds. Reforming Intergovernmental Fiscal Relations and the Rebuilding of Indonesia: The 'Big Bang' Program and its Economic Consequences, pp. 159-198. Edward Elgar, Cheltenham.

Central Bureau of Statistics (CBS). (various issues). Gross Regional Domestic Product of Provinces in Indonesia by Industrial Origin. Central Bureau of Statistics.

Garcia, J.G., and Soelistianingsih, L. (1998). Why do differences in provincial incomes persists in Indonesia? Bulletin of Indonesian Economic Studies, 34(1), 95-120.

Hill, H. (2008). Globalization, inequality, and local-level dynamics: Indonesia and the Philippines. Asian Economic Policy Review, 3, 42-61.

Hill, H., Resosudarmo, B.P. and Vidyattama, Y. (2008). Indonesia's changing economic geography. Bulletin of Indonesian Economic Studies, 44, 407-35.

Hill, H., and Vidyattama, Y. (2014). Hares and tortoises: regional development dynamics in Indonesia. In Regional Dynamics in a Decentralized Indonesia (Eds.) H. Hill, Singapore: Institute of South East Asian Studies, 68-97.

Hill, H. and Vidyattama, Y. (2016). Regional development dynamics In Indonesia defore and after the 'Big Bang' decentralization. The Singapore Economic Review, 61(2), 1-26.

Milanovic, B. (2005). Half a world: regional inequality in five great federations. Journal of the Asia Pacific Economy, 10, 408-45.

Resosudarmo, B.P. and Vidyattama, Y. (2006). Regional income disparity in Indonesia: A panel data analysis. ASEAN Economic Bulletin, 23, 31-44.

Rodrik, D. (2016). Premature deindustrialization. Journal of Economic Growth, 21(1): $1-33$.

Shorrocks, A. (1980). The class of additively decomposable inequality measures. Econometrica, 48(3), 613-25.

Shorrocks, A. (1982). Inequality decomposition by factor components. Econometrica 50(1), 193-211.

Soesastro, H., and Atje, R. (2005). Survey of recent developments. Bulletin of Indonesian Economic Studies, 41(1), 5-34. 
Tadjoeddin, M.Z., Suharyo, W.I. and Mishra, S. (2001). Regional disparity and vertical conflict in Indonesia. Journal of the Asia Pacific Economy, 6, 283-304.

Vidyattama, Y. (2010). A search for Indonesia's regional growth determinants. ASEAN Economic Bulletin, 27(3), 281-294

Vidyattama, Y. (2013). Regional convergence and the role of the neighborhood effect in decentralized Indonesia. Bulletin of Indonesian Economic Studies, 49(2), 193211 
Figure 1. Change in Industrial Structure (in \%)

GDP at 2000 Constant Prices

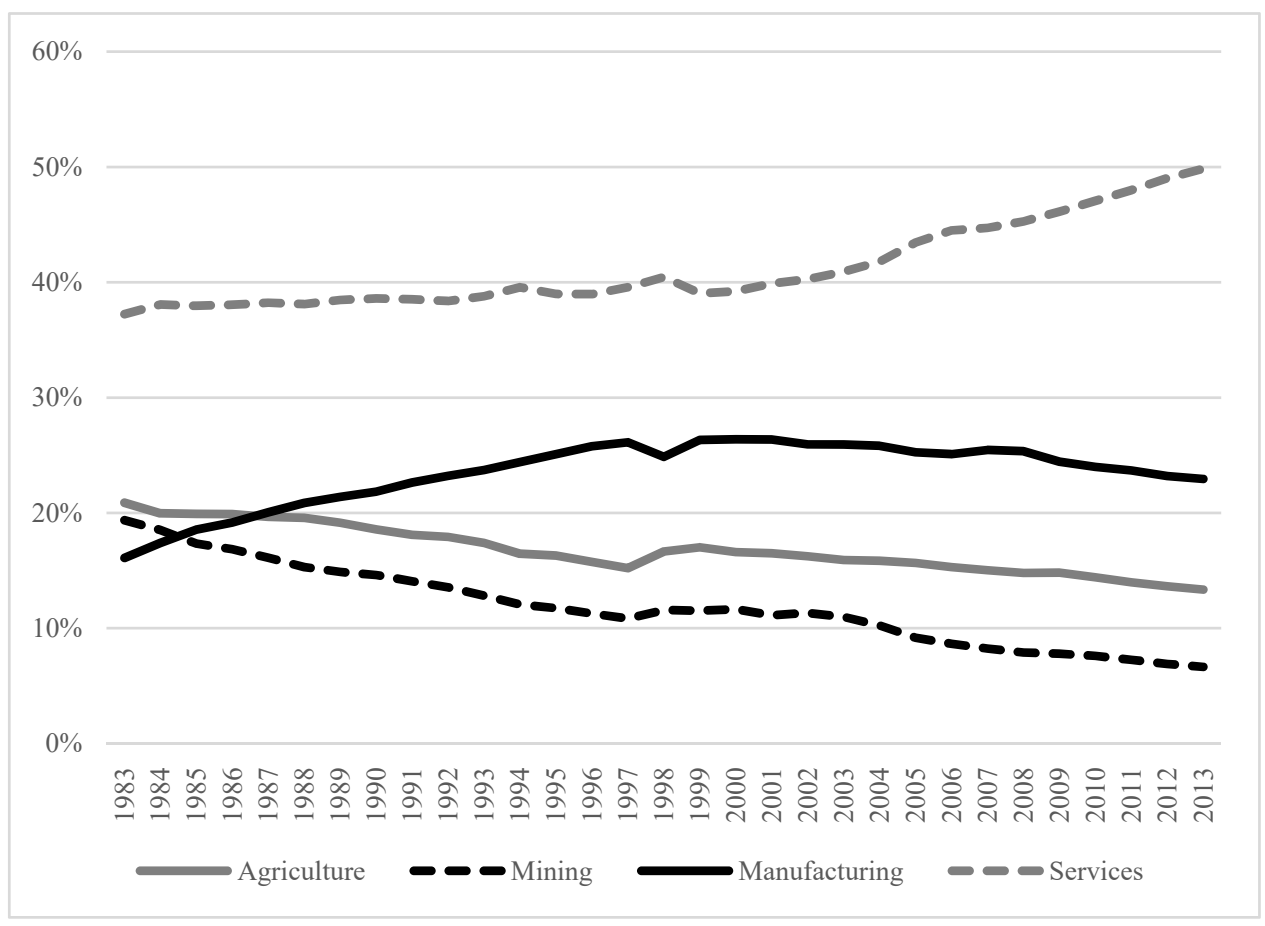

(Sources) Akita, Kurniawan and Miyata (2011) for 1983-2004; Central Bureau of Statistics (various issues), Gross Regional Domestic Product of Provinces in Indonesia by Industrial Origin for 2005-2013. 
Figure 2. Inter-provincial Inequality in Per Capita GDP at Constant 2000 Prices by squared $W C V$

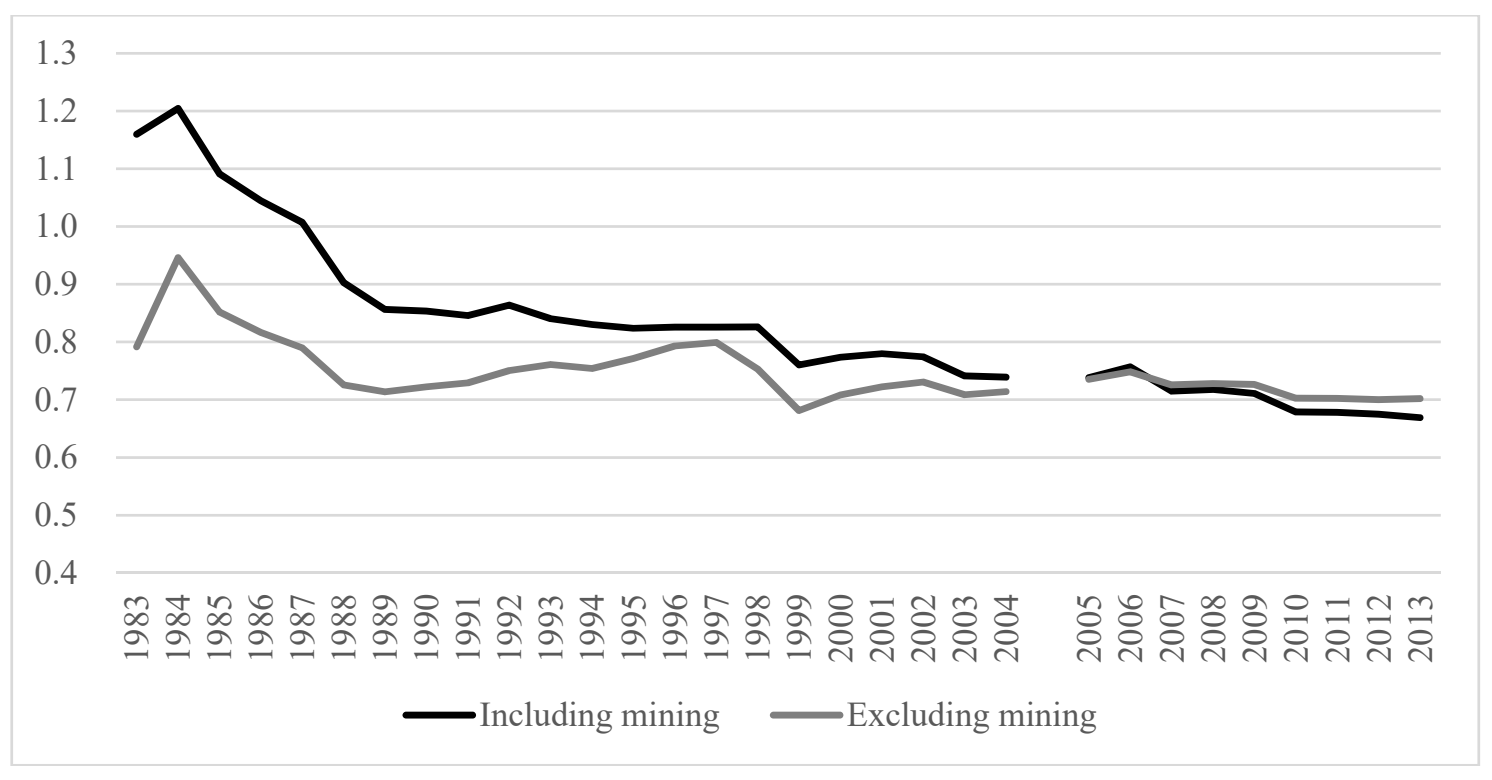

Jakarta merged with West Java

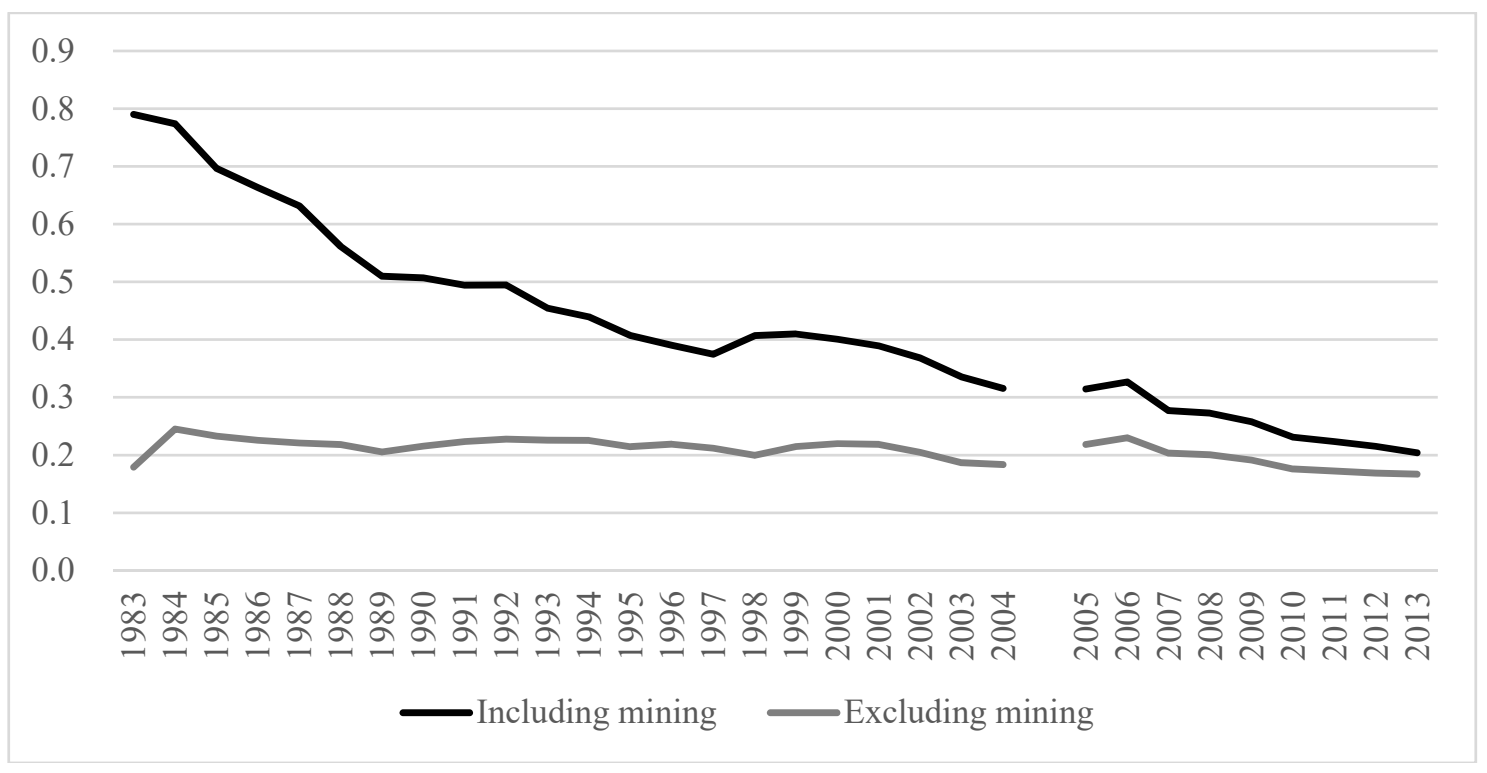

(Note) Inter-provincial inequality for 1983-2004 is across 26 provinces, while for 2004-2013, it is across 33 provinces.

(Sources) Akita, Kurniawan and Miyata (2011) for 1983-2004; Central Bureau of Statistics (various issues), Gross Regional Domestic Product of Provinces in Indonesia by Industrial Origin for 2005-2013. 
Table 1. Change in Industrial Structure and Annual Average Growth Rate by Sector (in \%)

GDP at 2000 Constant Prices

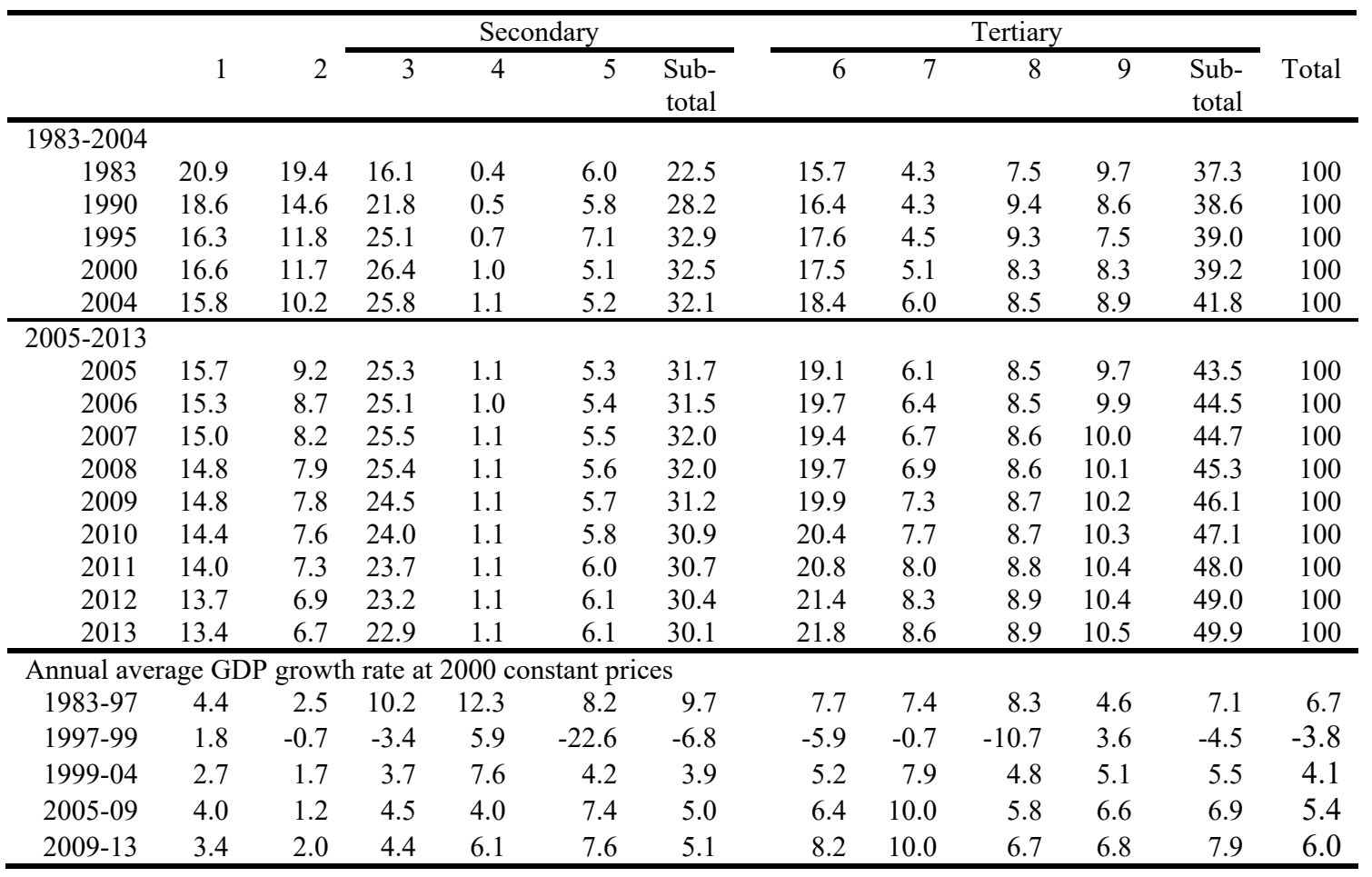

(Note) 1 agriculture, 2 mining, 3 manufacturing, 4 electricity/gas/water, 5 construction, 6 trade/hotel/restaurant, 7 transportation/communication, 8 financial and business services, and 9 other services.

(Source) Akita, Kurniawan and Miyata (2011) for the period from 1983 to 2004; Central Bureau of Statistics (various issues), Gross Regional Domestic Product of Provinces in Indonesia by Industry for the period from 2005 to 2013. 


\section{Table 2. Change in Geographical Structure (in \%) GDP at 2000 Constant Prices}

\begin{tabular}{|c|c|c|c|c|c|c|c|c|c|c|}
\hline \multirow[b]{3}{*}{ Provinces } & \multicolumn{5}{|c|}{ GDP including mining } & \multicolumn{5}{|c|}{ GDP excluding mining } \\
\hline & \multicolumn{3}{|c|}{ Share } & \multicolumn{2}{|c|}{ Growth rate } & \multicolumn{3}{|c|}{ Share } & \multicolumn{2}{|c|}{ Growth rate } \\
\hline & 1983 & 2005 & 2013 & $\begin{array}{r}1983- \\
04 \\
\end{array}$ & $\begin{array}{r}2005- \\
13 \\
\end{array}$ & 1983 & 2005 & 2013 & $\begin{array}{r}1983 \\
-04 \\
\end{array}$ & $\begin{array}{r}2005- \\
13 \\
\end{array}$ \\
\hline Sumatra & 26.9 & 21.8 & 20.8 & 2.3 & 5.1 & 18.9 & 19.2 & 19.2 & 3.8 & 6.1 \\
\hline Aceh & & 2.1 & 1.4 & & 0.6 & & 1.7 & 1.4 & & 3.5 \\
\hline North Sumatera & & 5.2 & 5.4 & & 6.1 & & 5.7 & 5.7 & & 6.1 \\
\hline West Sumatera & & 1.7 & 1.8 & & 5.9 & & 1.9 & 1.8 & & 6.0 \\
\hline Riau & & 4.6 & 4.1 & & 4.0 & & 2.3 & 2.5 & & 6.9 \\
\hline Jambi & & 0.7 & 0.8 & & 6.9 & & 0.7 & 0.8 & & 6.9 \\
\hline South Sumatera & & 2.9 & 2.9 & & 5.4 & & 2.4 & 2.5 & & 6.6 \\
\hline Bengkulu & & 0.4 & 0.4 & & 6.0 & & 0.4 & 0.4 & & 5.9 \\
\hline Lampung & & 1.7 & 1.7 & & 5.7 & & 1.9 & 1.8 & & 5.9 \\
\hline Bangka Belitung & & 0.5 & 0.5 & & 4.9 & & 0.5 & 0.5 & & 5.7 \\
\hline Riau Islands & & 1.8 & 1.9 & & 6.1 & & 1.8 & 1.9 & & 6.4 \\
\hline Kalimantan & 9.2 & 9.1 & 8.0 & 2.7 & 4.1 & 6.4 & 7.3 & 6.1 & 4.0 & 3.8 \\
\hline West Kalimantan & & 1.4 & 1.2 & & 4.3 & & 1.5 & 1.3 & & 4.2 \\
\hline Central Kalimantan & & 0.8 & 0.9 & & 6.2 & & 0.9 & 0.8 & & 5.5 \\
\hline South Kalimantan & & 1.4 & 1.4 & & 5.5 & & 1.2 & 1.1 & & 5.6 \\
\hline East Kalimantan & & 5.5 & 4.5 & & 3.3 & & 3.8 & 2.8 & & 2.5 \\
\hline Java-Bali & 57.5 & 61.3 & 63.0 & 4.1 & 6.0 & 68.0 & 66.5 & 66.7 & 4.2 & 6.1 \\
\hline Jakarta & & 17.8 & 18.3 & & 6.0 & & 19.5 & 19.5 & & 6.0 \\
\hline West Java & & 14.3 & 14.5 & & 5.8 & & 15.3 & 15.2 & & 6.0 \\
\hline Central Java & & 8.4 & 8.4 & & 5.6 & & 9.2 & 8.9 & & 5.6 \\
\hline Yogyakarta & & 1.0 & 0.9 & & 4.7 & & 1.1 & 1.0 & & 4.7 \\
\hline East Java & & 15.1 & 15.7 & & 6.2 & & 16.3 & 16.5 & & 6.1 \\
\hline Banten & & 3.4 & 4.0 & & 7.5 & & 3.8 & 4.2 & & 7.5 \\
\hline Bali & & 1.2 & 1.3 & & 6.3 & & 1.4 & 1.4 & & 6.3 \\
\hline Sulawesi & 3.3 & 4.4 & 5.1 & 4.8 & 7.5 & 3.9 & 4.5 & 5.1 & 4.6 & 7.5 \\
\hline North Sulawesi & & 0.8 & 0.9 & & 7.3 & & 0.8 & 0.9 & & 7.4 \\
\hline Central Sulawesi & & 0.7 & 0.9 & & 8.4 & & 0.8 & 0.9 & & 7.6 \\
\hline South Sulawesi & & 2.1 & 2.4 & & 7.1 & & 2.1 & 2.4 & & 7.5 \\
\hline South East Sulawesi & & 0.5 & 0.6 & & 7.8 & & 0.5 & 0.5 & & 7.4 \\
\hline Gorontalo & & 0.1 & 0.1 & & 7.3 & & 0.1 & 0.1 & & 7.3 \\
\hline West Sulawesi & & 0.2 & 0.2 & & 8.5 & & 0.2 & 0.2 & & 8.4 \\
\hline Eastern Indonesia & 3.1 & 3.4 & 3.2 & 3.7 & 4.6 & 2.8 & 2.5 & 2.9 & 3.4 & 7.7 \\
\hline West Nusa Tenggara & & 0.9 & 0.8 & & 3.7 & & 0.7 & 0.7 & & 5.7 \\
\hline East Nusa Tenggara & & 0.6 & 0.6 & & 5.0 & & 0.7 & 0.6 & & 5.0 \\
\hline Maluku & & 0.2 & 0.2 & & 5.6 & & 0.2 & 0.2 & & 5.6 \\
\hline North Maluku & & 0.1 & 0.1 & & 6.1 & & 0.1 & 0.1 & & 6.3 \\
\hline West Papua & & 0.3 & 0.6 & & 13.0 & & 0.3 & 0.6 & & 14.8 \\
\hline Papua & & 1.3 & 0.9 & & 1.3 & & 0.5 & 0.7 & & 9.4 \\
\hline Total & 100 & 100 & 100 & 3.5 & 5.7 & 100 & 100 & 100 & 4.1 & 6.0 \\
\hline
\end{tabular}

(Source) Akita, Kurniawan and Miyata (2011) for the period from 1983 to 2004; Central Bureau of Statistics (various issues), Gross Regional Domestic Product of Provinces in Indonesia by Industry for the period from 2005 to 2013. 
Table 3a. Average Annual Growth Rate of Per Capita GDP Including Mining: 05-09 and 09-13

\begin{tabular}{|c|c|c|c|c|c|c|c|c|c|c|c|}
\hline \multirow{3}{*}{ Code } & \multirow{3}{*}{ Province } & \multicolumn{6}{|c|}{ Per Capita GDP } & \multicolumn{4}{|c|}{ Growth rate of per capita GDP } \\
\hline & & \multicolumn{2}{|c|}{2005} & \multicolumn{2}{|c|}{2009} & \multicolumn{2}{|c|}{2013} & \multicolumn{2}{|c|}{ 05-09 } & \multicolumn{2}{|c|}{$09-13$} \\
\hline & & Value & Rank & Value & Rank & Value & Rank & Value & Rank & Value & Rank \\
\hline & Sumatra & & & & & & & & & & \\
\hline 11 & Aceh & 9,180 & 5 & 7,427 & 17 & 7,955 & 19 & -5.3 & 33 & 1.7 & 27 \\
\hline 12 & North Sumatera & 7,593 & 9 & 8,505 & 10 & 10,598 & 7 & 2.8 & 26 & 5.5 & 7 \\
\hline 13 & West Sumatera & 6,523 & 14 & 7,750 & 15 & 9,402 & 13 & 4.3 & 14 & 4.8 & 10 \\
\hline 14 & Riau & 17,388 & 4 & 17,690 & 4 & 18,099 & 5 & 0.4 & 30 & 0.6 & 30 \\
\hline 15 & Jambi & 4,853 & 23 & 5,798 & 23 & 6,746 & 24 & 4.4 & 13 & 3.8 & 18 \\
\hline 16 & South Sumatera & 7,426 & 10 & 8,498 & 11 & 9,918 & 8 & 3.4 & 21 & 3.9 & 17 \\
\hline 17 & Bengkulu & 4,080 & 27 & 4,766 & 27 & 5,598 & 27 & 3.9 & 18 & 4.0 & 15 \\
\hline 18 & Lampung & 4,170 & 25 & 4,887 & 26 & 5,906 & 26 & 4.0 & 15 & 4.7 & 11 \\
\hline 19 & Bangka Belitung & 8,392 & 7 & 9,075 & 6 & 9,875 & 10 & 2.0 & 28 & 2.1 & 24 \\
\hline \multirow[t]{2}{*}{21} & Riau Islands & 23,898 & 3 & 25,330 & 3 & 26,729 & 3 & 1.5 & 29 & 1.3 & 28 \\
\hline & Kalimantan & & & & & & & & & & \\
\hline 61 & West Kalimantan & 5,834 & 19 & 6,675 & 19 & 7,162 & 21 & 3.4 & 22 & 1.8 & 26 \\
\hline 62 & Central Kalimantan & 7,393 & 11 & 8,538 & 9 & 9,737 & 11 & 3.6 & 20 & 3.3 & 20 \\
\hline 63 & South Kalimantan & 7,142 & 13 & 8,336 & 13 & 9,421 & 12 & 3.9 & 19 & 3.1 & 22 \\
\hline \multirow[t]{2}{*}{64} & East Kalimantan & 33,102 & 2 & 33,396 & 2 & 31,559 & 2 & 0.2 & 31 & -1.4 & 33 \\
\hline & Java-Bali & & & & & & & & & & \\
\hline 31 & Jakarta & 34,333 & 1 & 41,400 & 1 & 49,241 & 1 & 4.7 & 11 & 4.3 & 14 \\
\hline 32 & West Java & 6,280 & 16 & 7,350 & 18 & 8,583 & 16 & 3.9 & 16 & 3.9 & 16 \\
\hline 33 & Central Java & 4,516 & 24 & 5,416 & 24 & 6,759 & 23 & 4.5 & 12 & 5.5 & 6 \\
\hline 34 & Yogyakarta & 5,189 & 21 & 5,864 & 22 & 6,993 & 22 & 3.1 & 25 & 4.4 & 13 \\
\hline 35 & East Java & 7,160 & 12 & 8,673 & 7 & 11,015 & 6 & 4.8 & 10 & 6.0 & 3 \\
\hline 36 & Banten & 6,490 & 15 & 8,585 & 8 & 9,308 & 14 & 7.0 & 1 & 2.0 & 25 \\
\hline \multirow[t]{2}{*}{51} & Bali & 6,257 & 17 & 7,710 & 16 & 8,605 & 15 & 5.2 & 9 & 2.7 & 23 \\
\hline & Sulawesi & & & & & & & & & & \\
\hline 71 & North Sulawesi & 6,129 & 18 & 7,848 & 14 & 9,884 & 9 & 6.2 & 3 & 5.8 & 5 \\
\hline 72 & Central Sulawesi & 5,195 & 20 & 6,618 & 20 & 8,347 & 17 & 6.1 & 4 & 5.8 & 4 \\
\hline 73 & South Sulawesi & 4,870 & 22 & 6,011 & 21 & 7,742 & 20 & 5.3 & 8 & 6.3 & 2 \\
\hline 74 & S.E. Sulawesi & 4,100 & 26 & 5,091 & 25 & 6,285 & 25 & 5.4 & 7 & 5.3 & 8 \\
\hline 75 & Gorontalo & 2,261 & 33 & 2,815 & 32 & 3,394 & 30 & 5.5 & 6 & 4.7 & 12 \\
\hline \multirow[t]{2}{*}{76} & West Sulawesi & 3,120 & 29 & 4,056 & 29 & 4,960 & 28 & 6.6 & 2 & 5.0 & 9 \\
\hline & Eastern Indonesia & & & & & & & & & & \\
\hline 52 & West Nusa Teng. & 3,674 & 28 & 4,295 & 28 & 4,383 & 29 & 3.9 & 17 & 0.5 & 31 \\
\hline 53 & East Nusa Teng. & 2,423 & 32 & 2,682 & 33 & 3,101 & 33 & 2.5 & 27 & 3.6 & 19 \\
\hline 81 & Maluku & 2,638 & 30 & 3,012 & 30 & 3,167 & 32 & 3.3 & 23 & 1.3 & 29 \\
\hline 82 & North Maluku & 2,568 & 31 & 2,919 & 31 & 3,320 & 31 & 3.2 & 24 & 3.2 & 21 \\
\hline 91 & West Papua & 7,761 & 8 & 9,854 & 5 & 18,252 & 4 & 6.0 & 5 & 15.4 & 1 \\
\hline \multirow[t]{3}{*}{94} & Papua & 9,125 & 6 & 8,444 & 12 & 8,157 & 18 & -1.9 & 32 & -0.9 & 32 \\
\hline & Total & 7,831 & & 9,125 & & 10,805 & & 3.8 & & 4.2 & \\
\hline & Ratio Max/Min & 15.2 & & 15.4 & & 15.9 & & & & & \\
\hline
\end{tabular}

(Source) Central Bureau of Statistics (various issues), Gross Regional Domestic Product of Provinces in Indonesia by Industry. 
Table 3b. Average Annual Growth Rate of Per Capita GDP Excluding Mining: 05-09 and 09-13

\begin{tabular}{|c|c|c|c|c|c|c|c|c|c|c|c|}
\hline \multirow{3}{*}{ Code } & \multirow{3}{*}{ Province } & \multicolumn{6}{|c|}{ Per Capita GDP } & \multicolumn{4}{|c|}{ Growth rate of per capita GDP } \\
\hline & & \multicolumn{2}{|c|}{2005} & \multicolumn{2}{|c|}{2009} & \multicolumn{2}{|c|}{2013} & \multicolumn{2}{|c|}{$05-09$} & \multicolumn{2}{|c|}{$09-13$} \\
\hline & & Value & Rank & Value & Rank & Value & Rank & Value & Rank & Value & Rank \\
\hline & Sumatra & & & & & & & & & & \\
\hline 11 & Aceh & 6,790 & 9 & 6,785 & 15 & 7,429 & 18 & 0.0 & 32 & 2.3 & 28 \\
\hline 12 & North Sumatera & 7,501 & 5 & 8,406 & 7 & 10,480 & 6 & 2.8 & 28 & 5.5 & 7 \\
\hline 13 & West Sumatera & 6,314 & 11 & 7,515 & 12 & 9,139 & 10 & 4.4 & 17 & 4.9 & 10 \\
\hline 14 & Riau & 7,767 & 4 & 8,854 & 4 & 10,209 & 7 & 3.3 & 24 & 3.6 & 21 \\
\hline 15 & Jambi & 4,248 & 23 & 5,136 & 23 & 5,907 & 23 & 4.7 & 11 & 3.5 & 22 \\
\hline 16 & South Sumatera & 5,457 & 18 & 6,582 & 16 & 8,019 & 15 & 4.7 & 14 & 4.9 & 9 \\
\hline 17 & Bengkulu & 3,952 & 25 & 4,594 & 26 & 5,411 & 27 & 3.8 & 21 & 4.1 & 17 \\
\hline 18 & Lampung & 4,044 & 24 & 4,789 & 25 & 5,789 & 24 & 4.2 & 18 & 4.7 & 11 \\
\hline 19 & Bangka Belitung & 6,946 & 7 & 7,748 & 10 & 8,665 & 11 & 2.7 & 29 & 2.8 & 25 \\
\hline \multirow[t]{2}{*}{21} & Riau Islands & 22,246 & 2 & 23,954 & 2 & 25,474 & 2 & 1.8 & 31 & 1.5 & 31 \\
\hline & Kalimantan & & & & & & & & & & \\
\hline 61 & West Kalimantan & 5,764 & 16 & 6,561 & 17 & 7,025 & 20 & 3.2 & 25 & 1.7 & 30 \\
\hline 62 & C. Kalimantan & 6,909 & 8 & 7,758 & 9 & 8,623 & 12 & 2.9 & 27 & 2.6 & 27 \\
\hline 63 & S. Kalimantan & 5,603 & 17 & 6,525 & 18 & 7,469 & 17 & 3.8 & 20 & 3.4 & 23 \\
\hline \multirow[t]{2}{*}{64} & East Kalimantan & 20,492 & 3 & 19,984 & 3 & 18,322 & 3 & -0.6 & 33 & -2.2 & 33 \\
\hline & Java-Bali & & & & & & & & & & \\
\hline 31 & Jakarta & 34,229 & 1 & 41,299 & 1 & 49,144 & 1 & 4.7 & 13 & 4.3 & 15 \\
\hline 32 & West Java & 6,096 & 14 & 7,171 & 14 & 8,439 & 14 & 4.1 & 19 & 4.1 & 18 \\
\hline 33 & Central Java & 4,470 & 21 & 5,356 & 22 & 6,684 & 22 & 4.5 & 15 & 5.5 & 6 \\
\hline 34 & Yogyakarta & 5,152 & 19 & 5,824 & 20 & 6,946 & 21 & 3.1 & 26 & 4.4 & 14 \\
\hline 35 & East Java & 7,020 & 6 & 8,482 & 6 & 10,789 & 5 & 4.7 & 12 & 6.0 & 4 \\
\hline 36 & Banten & 6,483 & 10 & 8,575 & 5 & 9,299 & 9 & 7.0 & 2 & 2.0 & 29 \\
\hline \multirow[t]{2}{*}{51} & Bali & 6,217 & 12 & 7,665 & 11 & 8,541 & 13 & 5.2 & 10 & 2.7 & 26 \\
\hline & Sulawesi & & & & & & & & & & \\
\hline 71 & North Sulawesi & 5,816 & 15 & 7,445 & 13 & 9,415 & 8 & 6.2 & 5 & 5.9 & 5 \\
\hline 72 & Central Sulawesi & 5,088 & 20 & 6,378 & 19 & 7,672 & 16 & 5.6 & 7 & 4.6 & 13 \\
\hline 73 & South Sulawesi & 4,384 & 22 & 5,524 & 21 & 7,180 & 19 & 5.8 & 6 & 6.6 & 3 \\
\hline 74 & S.E. Sulawesi & 3,866 & 26 & 4,831 & 24 & 5,702 & 25 & 5.6 & 8 & 4.1 & 16 \\
\hline 75 & Gorontalo & 2,241 & 33 & 2,785 & 32 & 3,358 & 30 & 5.4 & 9 & 4.7 & 12 \\
\hline \multirow[t]{2}{*}{76} & West Sulawesi & 3,103 & 28 & 4,014 & 28 & 4,910 & 28 & 6.4 & 4 & 5.0 & 8 \\
\hline & Eastern Indonesia & & & & & & & & & & \\
\hline 52 & West Nusa Teng. & 2,667 & 29 & 3,189 & 29 & 3,713 & 29 & 4.5 & 16 & 3.8 & 19 \\
\hline 53 & East Nusa Teng. & 2,391 & 32 & 2,649 & 33 & 3,061 & 33 & 2.6 & 30 & 3.6 & 20 \\
\hline 81 & Maluku & 2,616 & 30 & 2,991 & 30 & 3,143 & 32 & 3.3 & 23 & 1.2 & 32 \\
\hline 82 & North Maluku & 2,447 & 31 & 2,799 & 31 & 3,199 & 31 & 3.4 & 22 & 3.3 & 24 \\
\hline 91 & West Papua & 6,160 & 13 & 8,377 & 8 & 16,777 & 4 & 7.7 & 1 & 17.4 & 1 \\
\hline \multirow[t]{3}{*}{94} & Papua & 3,244 & 27 & 4,264 & 27 & 5,555 & 26 & 6.8 & 3 & 6.6 & 2 \\
\hline & Total & 7,111 & & 8,414 & & 10,086 & & 4.2 & & 4.5 & \\
\hline & Ratio Max/Min & 15.3 & & 15.6 & & 16.1 & & & & & \\
\hline
\end{tabular}

(Source) Central Bureau of Statistics (various issues), Gross Regional Domestic Product of Provinces in Indonesia by Industry. 
Table 4. Convergence across Provinces

\begin{tabular}{|c|c|c|c|c|c|c|c|c|}
\hline \multirow[b]{2}{*}{ Explanatory variables } & \multicolumn{3}{|c|}{$2005-2013$} & \multicolumn{3}{|c|}{$2005-2009$} & \multicolumn{2}{|c|}{$2009-2013$} \\
\hline & Coefficient & & t-value & Coefficient & & t-value & Coefficient & t-value \\
\hline Log per capita GDP in 2005 & -0.0133 & $* *$ & -2.22 & -0.0159 & $* *$ & -2.65 & & \\
\hline Log per capita GDP in 2009 & & & & & & & -0.0080 & -0.97 \\
\hline Java-Bali (dummy) & 0.0129 & & 1.35 & 0.0187 & $*$ & 1.95 & 0.0070 & 0.55 \\
\hline Constant & 0.0585 & $* * *$ & 5.03 & 0.1709 & $* * *$ & 3.26 & 0.1076 & 1.46 \\
\hline Speed of convergence & 0.0141 & & & 0.0164 & & & 0.0082 & \\
\hline Number of observations & 33 & & & 33 & & & 33 & \\
\hline R squared & 0.1670 & & & 0.2411 & & & 0.0346 & \\
\hline
\end{tabular}

(Note) *** significant at the $1 \%$ level; ** significant at the 5\% level; * significant at the $10 \%$ level.

(Source) Central Bureau of Statistics (various issues), Gross Regional Domestic Product of Provinces in Indonesia by Industry. 
Table 5. Interprovincial Inequality by Industrial Sector Measured by WCV

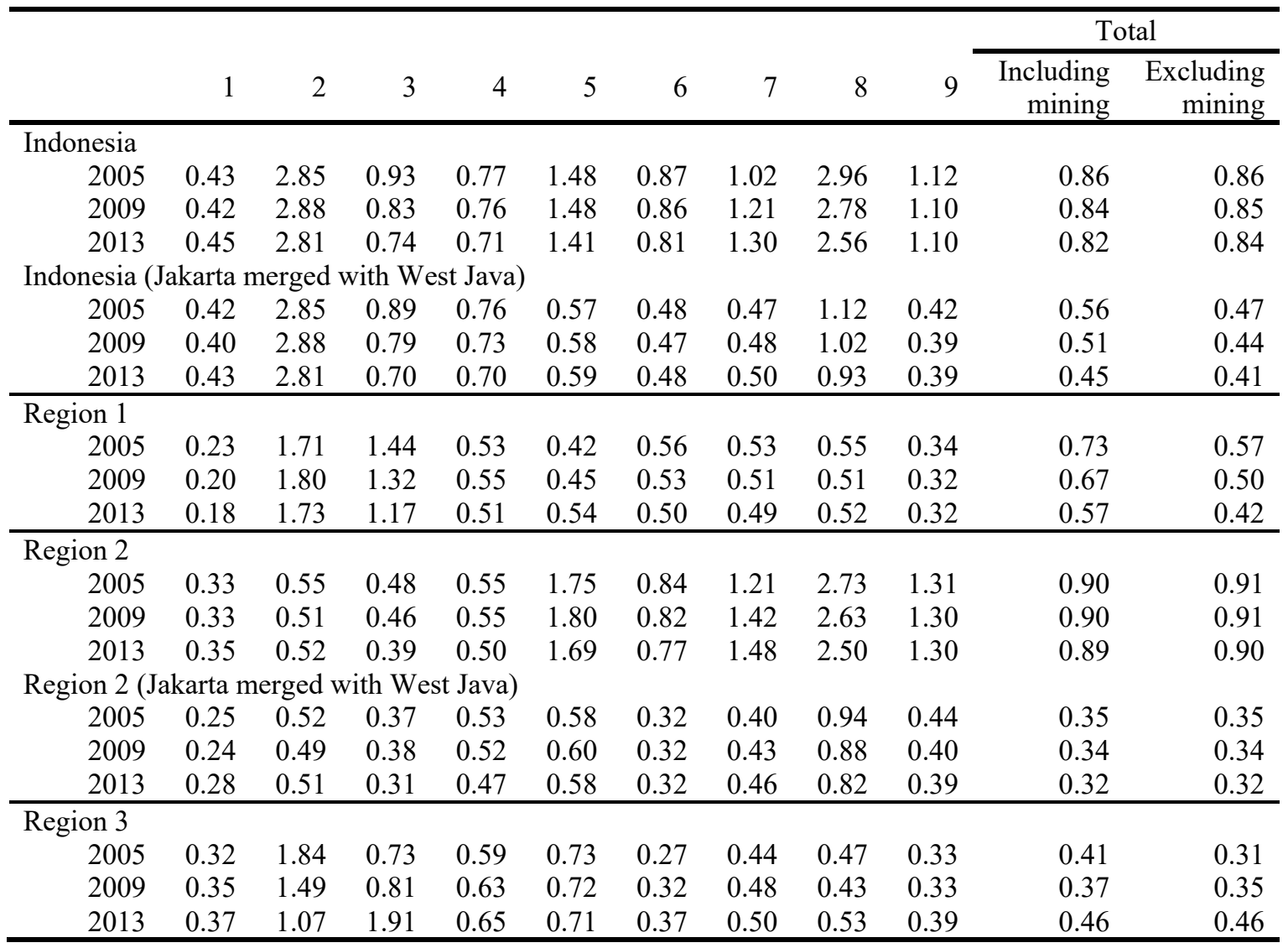

(Note) 1 agriculture, 2 mining, 3 manufacturing, 4 electricity/gas/water, 5 construction, 6 trade/hotel/restaurant, 7 transportation/communication, 8 financial and business services, and 9 other services.

(Source) Central Bureau of Statistics (various issues), Gross Regional Domestic Product of Provinces in Indonesia by Industry. 
Table 6. Change in Industrial Structure by Region (in \%)

\begin{tabular}{|c|c|c|c|c|c|c|c|c|c|c|c|c|}
\hline & \multirow[b]{2}{*}{1} & \multirow[b]{2}{*}{2} & \multicolumn{4}{|c|}{ Secondary } & \multicolumn{5}{|c|}{ Tertiary } & \multirow[b]{2}{*}{ Total } \\
\hline & & & 3 & 4 & 5 & $\begin{array}{l}\text { Sub- } \\
\text { total }\end{array}$ & 6 & 7 & 8 & 9 & $\begin{array}{l}\text { Sub- } \\
\text { total }\end{array}$ & \\
\hline \multicolumn{13}{|l|}{ Region 1} \\
\hline 2005 & 20.1 & 22.2 & 21.7 & 0.5 & 4.5 & 26.7 & 13.9 & 5.8 & 3.6 & 7.8 & 31.0 & 100 \\
\hline 2009 & 20.0 & 19.6 & 19.8 & 0.5 & 5.4 & 25.7 & 14.9 & 6.8 & 4.4 & 8.7 & 34.8 & 100 \\
\hline 2013 & 19.3 & 17.8 & 17.8 & 0.5 & 5.7 & 24.0 & 16.3 & 7.8 & 5.3 & 9.4 & 38.8 & 100 \\
\hline \multicolumn{13}{|l|}{ Region 2} \\
\hline 2005 & 11.7 & 1.4 & 29.3 & 1.6 & 5.5 & 36.3 & 22.5 & 6.1 & 11.6 & 10.3 & 50.5 & 100 \\
\hline 2009 & 10.7 & 1.3 & 28.7 & 1.4 & 5.6 & 35.8 & 23.1 & 7.4 & 11.2 & 10.5 & 52.1 & 100 \\
\hline 2013 & 9.1 & 1.1 & 26.9 & 1.4 & 6.0 & 34.3 & 25.0 & 8.9 & 11.0 & 10.6 & 55.5 & 100 \\
\hline \multicolumn{13}{|l|}{ Region 3} \\
\hline 2005 & 29.3 & 18.7 & 7.8 & 0.6 & 6.3 & 14.7 & 12.9 & 7.1 & 4.3 & 13.0 & 37.3 & 100 \\
\hline 2009 & 27.7 & 14.1 & 8.2 & 0.6 & 7.5 & 16.3 & 14.3 & 8.3 & 5.3 & 13.9 & 41.8 & 100 \\
\hline 2013 & 25.2 & 9.9 & 10.6 & 0.7 & 8.3 & 19.6 & 15.9 & 9.0 & 6.3 & 14.1 & 45.4 & 100 \\
\hline
\end{tabular}

(Note) 1 agriculture, 2 mining, 3 manufacturing, 4 electricity/gas/water, 5 construction, 6 trade/hotel/restaurant, 7 transportation/communication, 8 financial and business services, and 9 other services.

(Source) Central Bureau of Statistics (various issues), Gross Regional Domestic Product of Provinces in Indonesia by Industry. 
Table 7a. Bidimensional Decomposition of Inter-provincial Inequality by Squared WCV Including Mining: Contribution to Overall Inequality (in \%)

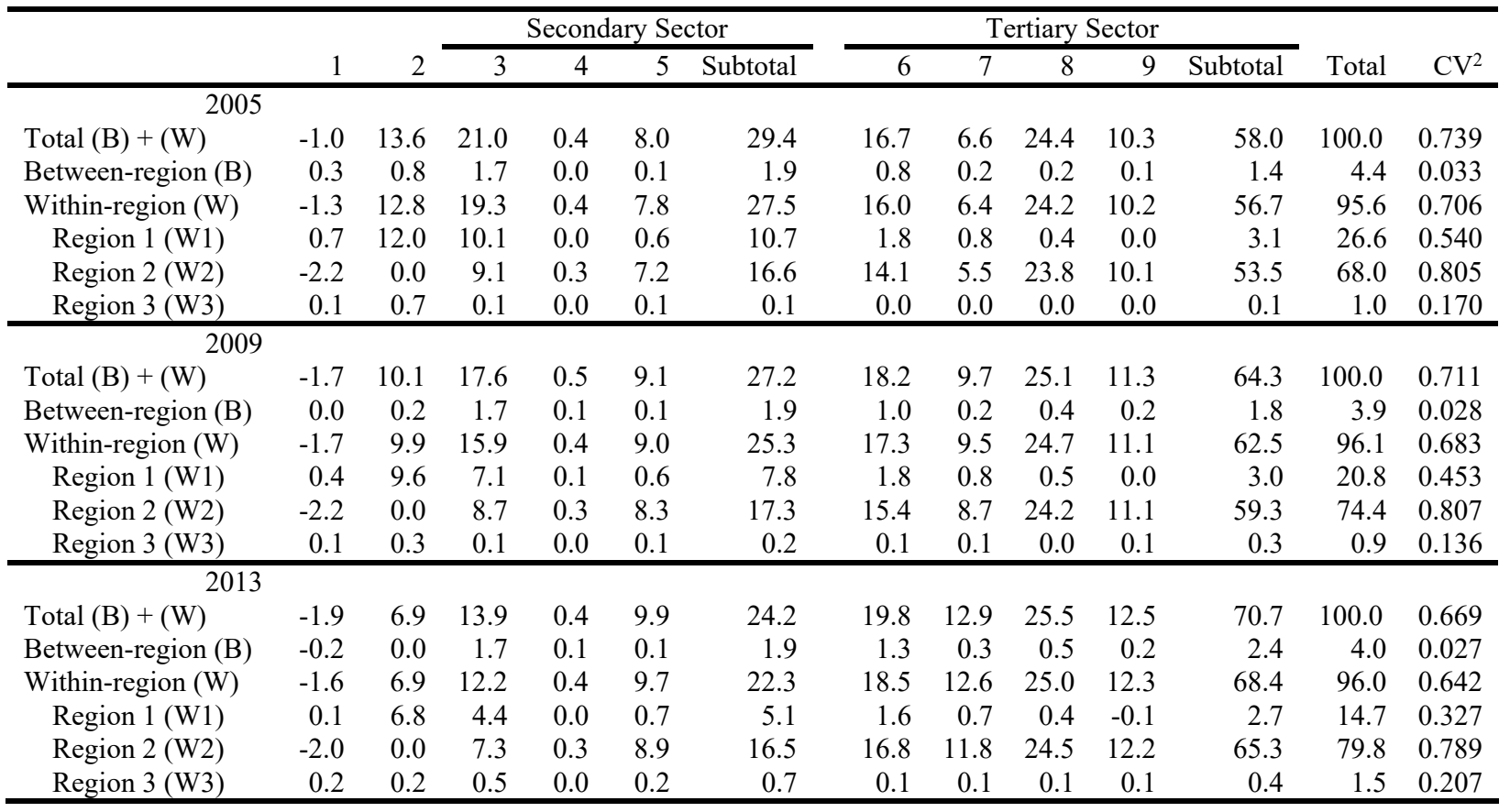

Jakarta Merged with West Java

\begin{tabular}{|c|c|c|c|c|c|c|c|c|c|c|c|c|c|}
\hline & \multirow[b]{2}{*}{1} & \multirow[b]{2}{*}{2} & \multicolumn{4}{|c|}{ Secondary Sector } & \multicolumn{5}{|c|}{ Tertiary Sector } & \multirow[b]{2}{*}{ Total } & \multirow[b]{2}{*}{$\mathrm{CV}^{2}$} \\
\hline & & & 3 & 4 & 5 & Subtotal & 6 & 7 & 8 & 9 & Subtotal & & \\
\hline \multicolumn{14}{|l|}{2005} \\
\hline Total $(\mathrm{B})+(\mathrm{W})$ & 1.8 & 32.3 & 34.5 & 0.5 & 3.9 & 38.9 & 10.6 & 4.1 & 8.9 & 3.4 & 27.0 & 100.0 & 0.315 \\
\hline Between-region (B) & 0.8 & 2.0 & 4.0 & 0.1 & 0.3 & 4.4 & 1.8 & 0.5 & 0.6 & 0.3 & 3.2 & 10.4 & 0.033 \\
\hline Within-region (W) & 1.0 & 30.3 & 30.5 & 0.5 & 3.5 & 34.5 & 8.8 & 3.6 & 8.3 & 3.1 & 23.8 & 89.6 & 0.282 \\
\hline Region 1 (W1) & 1.7 & 28.3 & 23.8 & 0.1 & 1.3 & 25.2 & 4.3 & 1.9 & 1.0 & 0.1 & 7.2 & 62.3 & 0.540 \\
\hline Region 2 (W2) & -0.9 & 0.4 & 6.7 & 0.3 & 2.1 & 9.1 & 4.5 & 1.6 & 7.3 & 2.9 & 16.3 & 24.9 & 0.125 \\
\hline Region 3 (W3) & 0.2 & 1.6 & 0.1 & 0.0 & 0.2 & 0.3 & 0.1 & 0.1 & 0.0 & 0.1 & 0.3 & 2.4 & 0.170 \\
\hline \multicolumn{14}{|l|}{2009} \\
\hline Total $(\mathrm{B})+(\mathrm{W})$ & 0.4 & 28.3 & 32.2 & 0.7 & 5.0 & 38.0 & 13.2 & 5.7 & 10.6 & 3.9 & 33.4 & 100.0 & 0.258 \\
\hline Between-region (B) & 0.0 & 0.6 & 4.7 & 0.1 & 0.4 & 5.2 & 2.7 & 0.6 & 1.2 & 0.5 & 4.9 & 10.8 & 0.028 \\
\hline Within-region (W) & 0.3 & 27.7 & 27.5 & 0.6 & 4.6 & 32.8 & 10.5 & 5.1 & 9.4 & 3.4 & 28.4 & 89.2 & 0.230 \\
\hline Region 1 (W1) & 1.0 & 26.5 & 19.7 & 0.1 & 1.8 & 21.6 & 4.9 & 2.2 & 1.2 & -0.1 & 8.2 & 57.3 & 0.453 \\
\hline Region 2 (W2) & -1.0 & 0.4 & 7.6 & 0.4 & 2.6 & 10.6 & 5.5 & 2.7 & 8.1 & 3.3 & 19.5 & 29.4 & 0.116 \\
\hline Region 3 (W3) & 0.4 & 0.8 & 0.3 & 0.0 & 0.3 & 0.6 & 0.2 & 0.2 & 0.1 & 0.2 & 0.7 & 2.4 & 0.136 \\
\hline \multicolumn{14}{|l|}{2013} \\
\hline Total $(\mathrm{B})+(\mathrm{W})$ & -1.0 & 22.9 & 28.5 & 0.8 & 6.4 & 35.7 & 17.0 & 8.0 & 12.5 & 4.9 & 42.3 & 100.0 & 0.204 \\
\hline Between-region (B) & -0.7 & -0.1 & 5.6 & 0.2 & 0.4 & 6.2 & 4.2 & 1.1 & 1.8 & 0.7 & 7.8 & 13.1 & 0.027 \\
\hline Within-region (W) & -0.2 & 23.0 & 22.9 & 0.6 & 6.0 & 29.5 & 12.8 & 6.9 & 10.7 & 4.2 & 34.5 & 86.9 & 0.177 \\
\hline Region 1 (W1) & 0.4 & 22.2 & 14.4 & 0.2 & 2.3 & 16.9 & 5.3 & 2.3 & 1.4 & -0.2 & 8.8 & 48.3 & 0.327 \\
\hline Region 2 (W2) & -1.3 & 0.2 & 6.8 & 0.4 & 3.2 & 10.5 & 7.0 & 4.2 & 9.0 & 4.0 & 24.3 & 33.6 & 0.101 \\
\hline Region 3 (W3) & 0.7 & 0.6 & 1.7 & 0.0 & 0.5 & 2.2 & 0.4 & 0.4 & 0.2 & 0.4 & 1.5 & 4.9 & 0.207 \\
\hline
\end{tabular}

(Notes) 1 agriculture, 3 manufacturing, 4 electricity/gas/water, 5 construction, 6 trade/hotel/restaurant, 7 transportation/communication, 8 financial and business services, and 9 other services.

(Source) Central Bureau of Statistics (various issues), Gross Regional Domestic Product of Provinces in Indonesia by Industry. 
Table 7b. Bidimensional Decomposition of Inter-provincial Inequality by Squared WCV Excluding Mining: Contribution to Overall Inequality (\%)

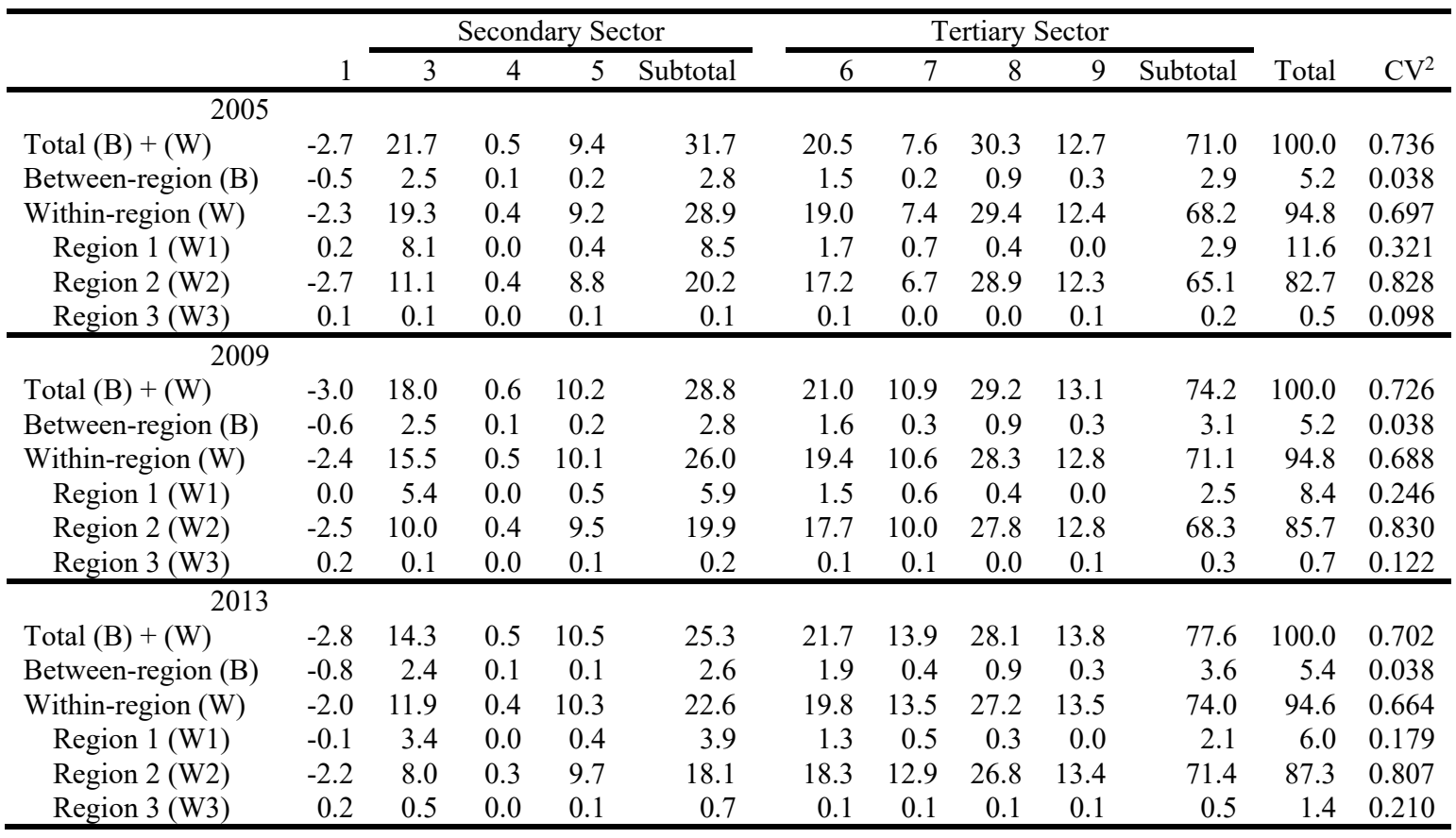

\section{Jakarta Merged with West Java}

\begin{tabular}{|c|c|c|c|c|c|c|c|c|c|c|c|c|}
\hline & & \multicolumn{4}{|c|}{ Secondary Sector } & \multicolumn{5}{|c|}{ Tertiary Sector } & \multirow[b]{2}{*}{ Total } & \multirow[b]{2}{*}{$\mathrm{CV}^{2}$} \\
\hline & 1 & 3 & 4 & 5 & Subtotal & 6 & 7 & 8 & 9 & Subtotal & & \\
\hline \multicolumn{13}{|c|}{2005} \\
\hline Total $(\mathrm{B})+(\mathrm{W})$ & -2.0 & 47.2 & 1.1 & 5.7 & 54.1 & 18.7 & 5.8 & 17.1 & 6.3 & 47.9 & 100.0 & 0.219 \\
\hline Between-region (B) & -1.5 & 8.2 & 0.4 & 0.6 & 9.3 & 5.0 & 0.7 & 2.9 & 1.0 & 9.6 & 17.4 & 0.038 \\
\hline Within-region (W) & -0.4 & 39.0 & 0.7 & 5.1 & 44.8 & 13.7 & 5.1 & 14.1 & 5.3 & 38.3 & 82.6 & 0.181 \\
\hline Region 1 (W1) & 0.7 & 27.3 & 0.1 & 1.3 & 28.8 & 5.9 & 2.2 & 1.5 & 0.1 & 9.7 & 39.2 & 0.321 \\
\hline Region 2 (W2) & -1.7 & 11.4 & 0.6 & 3.6 & 15.6 & 7.6 & 2.7 & 12.6 & 5.0 & 27.9 & 41.9 & 0.125 \\
\hline Region 3 (W3) & 0.5 & 0.3 & 0.0 & 0.2 & 0.5 & 0.2 & 0.2 & 0.1 & 0.2 & 0.7 & 1.6 & 0.098 \\
\hline \multicolumn{13}{|l|}{2009} \\
\hline Total $(\mathrm{B})+(\mathrm{W})$ & -3.4 & 42.4 & 1.4 & 6.7 & 50.4 & 20.8 & 7.8 & 17.9 & 6.6 & 53.0 & 100.0 & 0.191 \\
\hline Between-region (B) & -2.4 & 9.5 & 0.5 & 0.6 & 10.5 & 6.1 & 1.1 & 3.5 & 1.1 & 11.8 & 19.9 & 0.038 \\
\hline Within-region (W) & -1.0 & 32.9 & 0.9 & 6.1 & 39.9 & 14.6 & 6.7 & 14.4 & 5.5 & 41.2 & 80.1 & 0.153 \\
\hline Region 1 (W1) & 0.0 & 20.5 & 0.2 & 1.7 & 22.4 & 5.8 & 2.2 & 1.5 & 0.0 & 9.6 & 32.0 & 0.246 \\
\hline Region 2 (W2) & -1.7 & 11.9 & 0.7 & 4.1 & 16.7 & 8.5 & 4.2 & 12.7 & 5.1 & 30.6 & 45.6 & 0.116 \\
\hline Region 3 (W3) & 0.7 & 0.4 & 0.0 & 0.3 & 0.8 & 0.3 & 0.3 & 0.2 & 0.3 & 1.1 & 2.6 & 0.122 \\
\hline \multicolumn{13}{|l|}{2013} \\
\hline Total $(\mathrm{B})+(\mathrm{W})$ & -4.7 & 36.1 & 1.4 & 7.6 & 45.0 & 23.8 & 10.2 & 18.3 & 7.4 & 59.7 & 100.0 & 0.167 \\
\hline Between-region (B) & -3.4 & 10.0 & 0.5 & 0.6 & 11.2 & 8.0 & 1.8 & 3.9 & 1.3 & 15.0 & 22.8 & 0.038 \\
\hline Within-region (W) & -1.3 & 26.1 & 0.8 & 6.9 & 33.9 & 15.8 & 8.4 & 14.4 & 6.1 & 44.7 & 77.2 & 0.129 \\
\hline Region 1 (W1) & -0.3 & 14.3 & 0.2 & 1.9 & 16.3 & 5.6 & 2.0 & 1.5 & 0.0 & 9.0 & 25.0 & 0.179 \\
\hline Region 2 (W2) & -1.9 & 9.6 & 0.6 & 4.5 & 14.7 & 9.7 & 5.9 & 12.6 & 5.6 & 33.8 & 46.5 & 0.102 \\
\hline Region 3 (W3) & 0.9 & 2.2 & 0.0 & 0.6 & 2.8 & 0.6 & 0.5 & 0.3 & 0.5 & 1.9 & 5.7 & 0.210 \\
\hline
\end{tabular}

(Notes) 1 agriculture, 3 manufacturing, 4 electricity/gas/water, 5 construction, 6 trade/hotel/restaurant, 7 transportation/communication, 8 financial and business services, and 9 other services.

(Source) Central Bureau of Statistics (various issues), Gross Regional Domestic Product of Provinces in Indonesia by Industry. 
Table 8. Decomposition of $W C V$ by Manufacturing Subsectors in Region 1 (Sumatra and Kalimantan)

\begin{tabular}{|c|c|c|c|c|c|c|c|c|}
\hline \multirow[b]{2}{*}{ Manufacturing sector } & \multicolumn{4}{|c|}{2005} & \multicolumn{4}{|c|}{2013} \\
\hline & $w(\%)$ & $C V$ & $r$ & $\begin{array}{r}\begin{array}{r}\text { Contribution } \\
(\%)\end{array} \\
\end{array}$ & $w(\%)$ & $C V$ & $r$ & $\begin{array}{r}\text { Contribution } \\
(\%)\end{array}$ \\
\hline Petroleum refinery & 9.0 & 2.5 & 1.3 & 11.5 & 7.0 & 2.1 & 0.8 & 5.7 \\
\hline Liquid natural gas (LNG) & 24.5 & 3.7 & 2.0 & 49.1 & 11.9 & 3.7 & 1.5 & 18.0 \\
\hline Non-oil \& gas manufacturing & 66.5 & 1.3 & 0.6 & 39.4 & 81.1 & 1.3 & 0.9 & 76.3 \\
\hline Manufacturing total & 100.0 & 1.4 & & 100.0 & 100.0 & 1.2 & & 100.0 \\
\hline
\end{tabular}

(Note) $w$ is GDP share in \%, while $r$ is relative concentration ratio. Contribution is the contribution of each manufacturing subsector to inter-provincial inequality in per capita GDP for the manufacturing sector.

(Source) Central Bureau of Statistics (various issues), Gross Regional Domestic Product of Provinces in Indonesia by Industry. 

Table 9. Decomposition of WCV by Tertiary Subsectors
in Region 2 (Java and Bali)

\begin{tabular}{|c|c|c|c|c|c|c|c|c|}
\hline \multirow[b]{2}{*}{ Tertiary subsector } & \multicolumn{4}{|c|}{2005} & \multicolumn{4}{|c|}{2013} \\
\hline & $w(\%)$ & $C V$ & $r$ & $\begin{array}{r}\text { Contribution } \\
(\%)\end{array}$ & $w(\%)$ & $C V$ & $r$ & $\begin{array}{r}\text { Contribution } \\
(\%)\end{array}$ \\
\hline Wholesale \& retail trade & 35.5 & 0.8 & 0.6 & 20.1 & 36.6 & 0.7 & 0.5 & 19.4 \\
\hline Hotel & 1.8 & 1.8 & 0.8 & 1.5 & 1.6 & 1.7 & 0.7 & 1.2 \\
\hline Restaurants & 7.3 & 1.0 & 0.7 & 4.8 & 6.9 & 1.0 & 0.7 & 5.1 \\
\hline Trade/hotel/restaurant total & 44.6 & 0.8 & & 26.4 & 45.1 & 0.8 & & 25.7 \\
\hline Railways transportation & 0.1 & 0.7 & 0.5 & 0.1 & 0.1 & 0.9 & 0.6 & 0.1 \\
\hline Road transportation & 4.3 & 0.6 & 0.4 & 1.9 & 3.8 & 0.8 & 0.5 & 2.0 \\
\hline Sea transportation & 1.0 & 2.1 & 1.5 & 1.5 & 0.7 & 2.0 & 1.5 & 1.0 \\
\hline River, lake \& ferry transportation & 0.0 & 1.7 & -0.1 & 0.0 & 0.0 & 2.1 & -0.1 & 0.0 \\
\hline Air transportation & 0.9 & 1.4 & -0.1 & -0.1 & 1.1 & 1.1 & -0.1 & -0.2 \\
\hline Services allied to transportation & 1.6 & 1.3 & 0.8 & 1.3 & 1.5 & 1.3 & 1.0 & 1.5 \\
\hline Information \& communication & 4.2 & 1.9 & 1.4 & 5.7 & 8.8 & 2.0 & 1.6 & 13.6 \\
\hline Transportation/communication total & 12.1 & 1.2 & & 10.3 & 16.0 & 1.5 & & 18.1 \\
\hline Bank & 11.4 & 3.3 & 2.3 & 26.3 & 8.7 & 2.9 & 2.2 & 19.2 \\
\hline Non-bank financial institution & 2.0 & 2.5 & 1.8 & 3.4 & 2.0 & 2.3 & 1.7 & 3.5 \\
\hline Services allied to finance & 0.2 & 3.0 & 2.1 & 0.4 & 0.2 & 3.0 & 2.2 & 0.4 \\
\hline Real estate & 5.1 & 1.6 & 1.1 & 5.8 & 4.8 & 1.5 & 1.2 & 5.6 \\
\hline Business services & 4.3 & 2.8 & 2.0 & 8.4 & 4.0 & 2.8 & 2.2 & 8.7 \\
\hline Financial \& business services total & 22.9 & 2.7 & & 44.3 & 19.8 & 2.5 & & 37.4 \\
\hline General government & 8.3 & 0.6 & 0.4 & 3.3 & 6.3 & 0.6 & 0.4 & 2.2 \\
\hline Private services & 9.5 & 1.7 & 1.2 & 11.8 & 10.4 & 1.6 & 1.2 & 12.7 \\
\hline Social \& community services & 2.5 & 2.2 & 1.6 & 3.9 & 2.4 & 2.2 & 1.6 & 3.9 \\
\hline Other services total & 20.4 & 1.3 & & 19.0 & 19.1 & 1.3 & & 18.8 \\
\hline Tertiary sector total & 100.0 & 1.4 & & 100.0 & 100.0 & 1.3 & & 100.0 \\
\hline
\end{tabular}

Jakarta Merged with West Java

\begin{tabular}{|c|c|c|c|c|c|c|c|c|}
\hline \multirow[b]{2}{*}{ Tertiary subsector } & \multicolumn{4}{|c|}{2005} & \multicolumn{4}{|c|}{2013} \\
\hline & $w(\%)$ & $C V$ & $r$ & $\begin{array}{r}\text { Contribution } \\
(\%)\end{array}$ & $w(\%)$ & $C V$ & $r$ & $\begin{array}{r}\text { Contribution } \\
(\%)\end{array}$ \\
\hline Wholesale \& retail trade & 35.5 & 0.3 & 0.6 & 22.0 & 36.6 & 0.3 & 0.7 & 24.3 \\
\hline Hotel & 1.8 & 1.4 & 0.8 & 1.4 & 1.6 & 1.4 & 0.6 & 1.1 \\
\hline Restaurants & 7.3 & 0.3 & 0.5 & 3.8 & 6.9 & 0.3 & 0.6 & 3.9 \\
\hline Trade/hotel/restaurant total & 44.6 & 0.3 & & 27.2 & 45.1 & 0.3 & & 29.3 \\
\hline Railways transportation & 0.1 & 0.5 & 0.9 & 0.1 & 0.1 & 0.4 & 0.9 & 0.1 \\
\hline Road transportation & 4.3 & 0.3 & 0.5 & 2.0 & 3.8 & 0.3 & 0.4 & 1.6 \\
\hline Sea transportation & 1.0 & 0.6 & 1.1 & 1.1 & 0.7 & 0.5 & 0.9 & 0.6 \\
\hline River, lake \& ferry transportation & 0.0 & 1.7 & -1.1 & 0.0 & 0.0 & 2.1 & -1.5 & 0.0 \\
\hline Air transportation & 0.9 & 1.4 & -0.7 & -0.6 & 1.1 & 1.0 & -0.3 & -0.4 \\
\hline Services allied to transportation & 1.6 & 0.6 & 0.6 & 0.9 & 1.5 & 0.5 & 0.7 & 1.1 \\
\hline Information \& communication & 4.2 & 0.7 & 1.5 & 6.0 & 8.8 & 0.7 & 1.6 & 14.1 \\
\hline Transportation/communication total & 12.1 & 0.4 & & 9.5 & 16.0 & 0.5 & & 17.1 \\
\hline Bank & 11.4 & 1.2 & 2.4 & 26.9 & 8.7 & 1.0 & 2.3 & $\overline{19.6}$ \\
\hline Non-bank financial institution & 2.0 & 0.8 & 1.7 & 3.4 & 2.0 & 0.7 & 1.7 & 3.4 \\
\hline Services allied to finance & 0.2 & 1.0 & 1.8 & 0.4 & 0.2 & 1.0 & 1.8 & 0.3 \\
\hline Real estate & 5.1 & 0.5 & 1.1 & 5.4 & 4.8 & 0.4 & 0.9 & 4.4 \\
\hline Business services & 4.3 & 1.0 & 2.0 & 8.7 & 4.0 & 1.0 & 2.2 & 8.9 \\
\hline Financial \& business services total & 22.9 & 0.9 & & 44.7 & 19.8 & 0.8 & & 36.6 \\
\hline General government & 8.3 & 0.3 & 0.2 & 1.7 & 6.3 & 0.3 & -0.2 & -1.3 \\
\hline Private services & 9.5 & 0.6 & 1.4 & 12.9 & 10.4 & 0.6 & 1.4 & 14.6 \\
\hline Social \& community services & 2.5 & 0.8 & 1.6 & 3.9 & 2.4 & 0.7 & 1.5 & 3.7 \\
\hline Other services total & 20.4 & 0.4 & & 18.5 & 19.1 & 0.4 & & 17.0 \\
\hline Tertiary sector total & 100.0 & 0.5 & & 100.0 & 100.0 & 0.4 & & 100.0 \\
\hline
\end{tabular}

(Note) $w$ is GDP share in \%, while $r$ is relative concentration ratio. Contribution is the contribution of each tertiary subsector to inter-provincial inequality in per capita GDP for the tertiary sector.

(Source) Central Bureau of Statistics (various issues), Gross Regional Domestic Product of Provinces in Indonesia by Industry. 


\section{Appendix}

Table A1. Sector Classification

\begin{tabular}{|c|c|c|c|c|c|}
\hline & \multirow[t]{2}{*}{9 sectors } & \multirow[t]{2}{*}{33 sectors } & \multicolumn{3}{|c|}{$\begin{array}{l}\text { GDP at constant } 2000 \text { prices } \\
\text { (share in \%) }\end{array}$} \\
\hline & & & 2005 & 2009 & 2013 \\
\hline 1 & Agriculture & food crops & 7.7 & 7.2 & 6.2 \\
\hline 2 & & estate crops & 3.3 & 3.2 & 3.1 \\
\hline 3 & & livestock & 1.9 & 1.8 & 1.7 \\
\hline 4 & & forestry & 0.9 & 0.8 & 0.6 \\
\hline 5 & & fishery & 1.8 & 1.9 & 1.8 \\
\hline 6 & Mining & oil \& gas mining & 5.9 & 4.5 & 3.4 \\
\hline 7 & & non-oil \& gas mining & 2.6 & 2.6 & 2.5 \\
\hline 8 & & quarrying & 0.7 & 0.8 & 0.8 \\
\hline 9 & Manufacturing & petroleum refinery & 1.3 & 1.1 & 0.9 \\
\hline 10 & & liquified natural gas (LNG) & 1.6 & 1.1 & 0.8 \\
\hline 11 & & non-oil \& gas manufacturing & 22.3 & 22.3 & 21.3 \\
\hline 12 & Electricity/gas/water & electricity & 0.9 & 0.8 & 0.8 \\
\hline 13 & & city gas & 0.1 & 0.2 & 0.1 \\
\hline 14 & & water supply & 0.1 & 0.1 & 0.1 \\
\hline 15 & Construction & construction & 5.3 & 5.7 & 6.1 \\
\hline 16 & Trade/hotel/restaurant & wholesale \& retail trade & 15.8 & 16.6 & 18.2 \\
\hline 17 & & hotel & 0.7 & 0.7 & 0.7 \\
\hline 18 & & restaurants & 2.6 & 2.6 & 2.8 \\
\hline 19 & Transportation/communication & railways transport & 0.1 & 0.1 & 0.0 \\
\hline 20 & & road transport & 2.3 & 2.4 & 2.5 \\
\hline 21 & & sea transport & 0.6 & 0.5 & 0.5 \\
\hline 22 & & river, lake \& ferry transport & 0.1 & 0.1 & 0.1 \\
\hline 23 & & air transport & 0.6 & 0.7 & 0.9 \\
\hline 24 & & services allied to transport & 0.7 & 0.8 & 0.8 \\
\hline 25 & & information \& communication & 1.7 & 2.8 & 3.8 \\
\hline 26 & Financial \& business services & bank & 4.0 & 3.8 & 3.9 \\
\hline 27 & & non-bank financial institution & 0.7 & 0.8 & 0.9 \\
\hline 28 & & services allied to finance & 0.1 & 0.1 & 0.1 \\
\hline 29 & & real estate & 2.3 & 2.4 & 2.5 \\
\hline 30 & & business services & 1.5 & 1.5 & 1.6 \\
\hline 31 & Other services & general government & 5.0 & 5.0 & 4.9 \\
\hline 32 & & private & 3.7 & 4.1 & 4.5 \\
\hline 33 & & social \& community services & 1.0 & 1.1 & 1.1 \\
\hline & Total & & 100.0 & 100.0 & 100.0 \\
\hline
\end{tabular}

